\title{
Phytoplankton dynamics associated with a geostrophic front: Ecological and biogeochemical implications
}

\author{
by Hervé Claustre ${ }^{1}$, Philippe Kerhervé ${ }^{1}$, Jean Claude Marty ${ }^{1}$, Louis Prieur ${ }^{1}$, \\ Christianne Videau ${ }^{2}$ and Jean-Henri Hecq ${ }^{3}$
}

\begin{abstract}
Using phytoplankton pigments as biomarkers, we investigated the relationship between the physical forcing and the resulting biological, ecological and biogeochemical properties of the geostrophic front of the Eastern Alboran Sea. (1) Typical frontal sites present biomass levels averaging $60 \mathrm{mg} \mathrm{chl} a \mathrm{~m}^{-2}$ (up to $100 \mathrm{mg} \mathrm{m}^{-2}$ ), whereas the adjacent zones (typical Atlantic and Mediterranean) are characterized by an average integrated chlorophyll biomass of $20 \mathrm{mg}$ chl $a \mathrm{~m}^{-2}$. (2) The phytoplankton biomass at front is diatom-dominated and differs markedly from the adjacent zones (typical Atlantic and Mediterranean), flagellate- and cyanobacteriadominated. Therefore, high biomasses at the front do not result from purely physical accumulation but rather from local production. (3) The chlorophyll and diatom biomasses increase from the left to the right side of the Atlantic jet, which supports the hypothesis of a cross-frontal secondary circulation allowing a diatom bloom development. (4) Using assumptions on the carbon/chlorophyll ratio and growth rates for the different phytoplankton taxa, we evaluated the specific productions: diatoms account for $67 \%$ of the production at front and only about $10 \%$ at adjacent zones. (5) High concentrations of phaeopigments are only found at frontal stations, which points out the pecularities of the food web at the frontal site, compared to adjacent areas. (6) The observations made during this study give a precise picture of that frontal system: autotrophic new production and exportation are enhanced. The implication of this frontal system on the carbon budget at a regional scale may be important.
\end{abstract}

\section{Introduction}

Physical singularities in the sea are at the origin of biological peculiarities, especially when the scales of physics and biology are coincident (Harris, 1980; Fogg, 1991). Oceanic frontal systems are well-known structures where such coincidences occur (Weller, 1990; Sournia et al., 1990). The physical and ecological structures of shelf zone fronts are well-documented (e.g. Pingree et al., 1975; Pingree and Mardell, 1981; Le Fèvre, 1986; Videau, 1987). In contrast, open-ocean persistent frontal systems associated with geostrophic jets have been less well studied. These frontal structures are, however, particularly interesting for three reasons: (1) like all frontal

1. Observatoire Océanologique de Villefranche, CNRS-INSU, Laboratoire de Physique et Chimie Marines, B.P. 08, 06230 Villefranche-sur-mer France.

2. Physiologie végétale, Faculté des Sciences, Avenue Le Gorgeu, 29287 Brest Cedex France.

3. Ecohydrodynamique, Université de Liège, B5, Start Tilman, 4000 Liège, Belgium. 
systems, they present a diversity of biological and ecological adaptation processes. The analysis of these processes is essential to gain understanding of the biological reactions to the physical forcing (Sournia et al., 1990). (2) In open-ocean frontal-jet systems, the main flow (primary circulation) is not strictly in geostrophic balance. Consequently a secondary ageostrophic circulation takes place in the form of vertical and horizontal ageostrophic velocities (Bower and Rossby, 1989; Arnone et al., 1990; Dewey et al., 1991). This secondary circulation may determine the biological properties of the frontal system: nutrients may be upwelled to the photic layer and assimilated by phytoplankton which are subsequently downwelled to deeper layers. This secondary circulation, in addition with otrer mixing (essentially diffusive) processes, can be therefore responsible for enhanced biomass and production (Boucher et al., 1987; Franks, 1992a). (3) Although such areas are relatively scarce in the ocean, their influence may nevertheless be significant at a regional or global scale (Lohrenz et al., 1988a), a significance which remains to be quantified.

The jet of North-Atlantic waters that flows into the more saline Mediterranean water through the strait of Gibraltar creates a geostrophic front (Cheney and Doblar, 1982). Detailed investigations of this area have shown that the circulation associated with the jet inflow is at the origin of two anticyclonic gyres (West Alboran and East Alboran Gyres) as described in Heburn and La Violette (1987) and Tintore et al. (1988). In particular, at the east side of the Alboran Sea, the confrontation of the jet flow (the so-called modified Atlantic waters) with the resident Mediterranean waters (east of the second gyre) results in the formation of an intense front named the Almeria-Oran front. The position of the front from Almeria to Oran is probably related to the existence of the Eastern Gyre (Heburn and La Violette, 1990). Although the permanence of this physical structure is established (Tintoré $e t$ al., 1988), the permanence of associated biological features remains to be demonstrated. Since 1986, several intensive investigations have focused on this area. Tintore $e t$ al. (1988) have described the hydrological and physical structure of the front, but the real influence of this structure on biological production was not investigated. Gould and Wiesenburg (1990) described one station located on the front with an exceptional biological pattern for an oceanic area. Lohrenz et al. $(1988 \mathrm{a}, \mathrm{b})$ focused on physical-biological interactions, but their work took place near the Algerian current which is the western extension of the jet studied here.

In spring 1991, a multidisciplinary study of the Almeria-Oran front was performed to evaluate the effect of this peculiar physical structure on the resultant biological, ecological and biogeochemical properties (Prieur et al., 1993). The main goals of the present investigation were focused on autotrophic biomass and production, which are the essential links between the physical forcing and the resulting biogeochemical properties of the frontal system. However, for the study of such a highly dynamic area it is necessary to sample with a higher spatial frequency than elsewhere. For some physico-chemical parameters (current velocity, temperature, salinity, oxygen), con- 
tinuous towed instruments (ADCP, CTD) allow real time sampling for most of environmental conditions. For biological variables, like phytoplankton, high sampling rate is difficult to achieve (except for in vivo fluorescence which gives an equivalent of the overall biomass distribution). Pigment HPLC analysis is a good compromise to investigate the level and the dynamic of a phytoplankton community. This method evaluates not only the overall phytoplankton biomass (chlorophyll $a$ ), but also a variety of phytoplankton accessory pigments (carotenoids and chlorophylls), most of which give informations on taxonomy or on processes that affect the fate of phytoplankton populations (Everitt et al., 1990; Ondrusek et al., 1991; Williams and Claustre, 1991; Barlow et al., 1993).

The present paper focuses on a study of carotenoid and chlorophyll pigments to infer the specificity of a frontal system in regards to its environment. From a synoptic description of the Alboran basin and detailed investigations at particular sites, the following questions are posed: what are the peculiarities (qualitative and quantitative) of phytoplankton biomass (horizontal and vertical distribution) associated with the jet-front system? Is this frontal biomass the result of a passive accumulation or of local enhanced production? Although the physical features of such a system are persistent, are biological features accordingly persistent or temporally/spatially limited? What is the fate of the frontal phytoplanktonic biomass?

\section{Material and methods}

The "Almofront 1" cruise was undertaken in the Alboran Basin from April 24 to May 26, 1991 onboard research vessel L'Atalante. The objectives of the cruise as well as the sampling strategy have been extensively described in Prieur et al. (1993). Briefly, the cruise was partitioned into two legs. Leg A consisted of a synoptic description of the whole Alboran basin (Fig. 1A) using 83 CTD-rosette stations (sampling down to $1000 \mathrm{~m}$ or bottom), tow-yo sections (CTD-oxygen-fluorescence, down to $600 \mathrm{~m}$ ), and towed hydroelectric system transects (THES, down to $200 \mathrm{~m}$ ), (Prieur et al., 1993). ADCP (RDI, $150 \mathrm{khz}$ ) was working during these operations. This strategy allowed us to locate the Atlantic jet and to describe its general physical, hydrological and biological features. Leg B was mostly dedicated to process studies at selected sites, identified during the first leg and located in and near the jet (Figure 1B). As the hydrological and biological structures appeared strongly variable in the transverse jet direction, but weakly in the along jet direction (see below), we defined a site as a set of stations performed during the 36 hours drift of a sediment trap mooring (100 and $300 \mathrm{~m}$ depth). For each site, about 12 hydrological casts were performed. The positions and drift trends for the 6 sites, numbered in the same order as they were explored, are shown in Figure 1B. From hydrological and current (ADCP) data, the starting stations were chosen in order to obtain a virtual cross section of the jet at the end of leg $B$. 


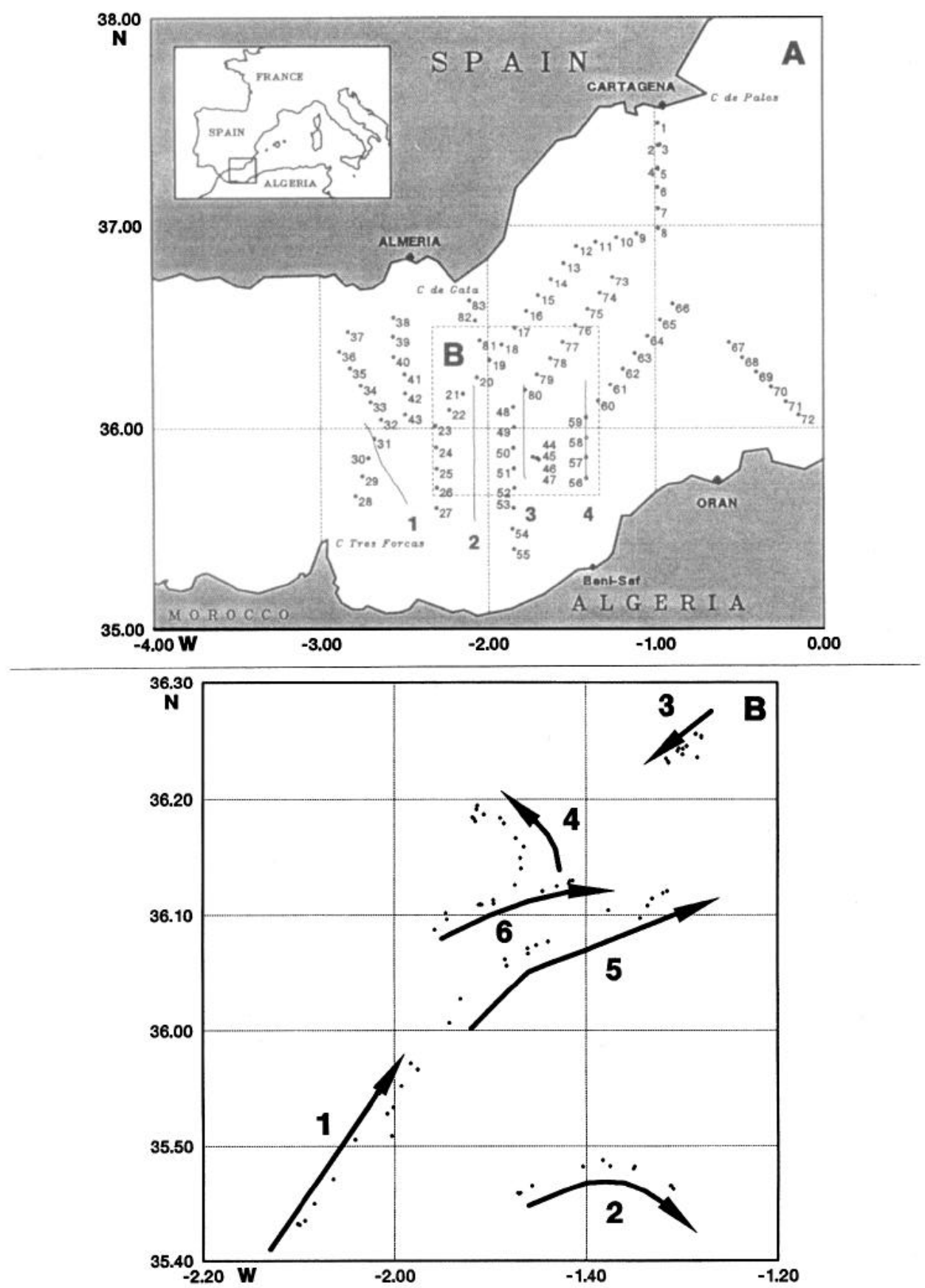

Figure 1. Map of the investigated area during Almofront 1. (A) Leg A (April 24-May 12). The location of the 83 investigated stations are reported as well as the tow-yo transects. The dashed box represents the box of Figure 1B. (B) Leg B (May 13-26). The arrows show the drifts of the sediment traps and the dots the location of the CTD stations. 


\section{a. Sampling and pigment analysis}

The rosette sampling depths were chosen on the basis of the in situ fluorescence signal recorded during the descent of the CTD. During leg A, 50 stations out of the 83 were analyzed with 8 depths sampled in the photic zone. During leg B, 4 profiles with 12 sampled depths were devoted to HPI C analyses at each site, except for site 4 (2 profiles). Two to four liters of seawater were filtered through $47 \mathrm{~mm} \mathrm{GF} / \mathrm{F}$ glass fiber filters which were transferred to $5 \mathrm{ml}$ methanol at $-80^{\circ} \mathrm{C}$ for $30 \mathrm{~min}$. Pigment extraction was completed using a sonication probe, and the extract was subsequently clarified by filtration. HPLC analysis followed the procedure used by Mantoura and Llewellyn (1983) and Williams and Claustre (1991), except that the flow rate was set at $1 \mathrm{ml} \mathrm{min}{ }^{-1}$. Two variable wavelength Milton Roy detectors were used in series, one set up at $440 \mathrm{~nm}$ (carotenoids and chlorophylls), and the other at $667 \mathrm{~nm}$ (chlorophylls and their degradation products). In the absence of precise information on the structure of chlorophyll degradation products, phaeopigments will refer to the sum of 5 phaeophorbides and one phaeophytin, and chlorophyllids to the sum of 4 different chlorophyllid-types. The identification of pigments was achieved by oneline diode array detection (Waters 991) on selected samples. Detectors were calibrated using pigment standards provided by $\mathrm{R}$. Bidigare as part of a JGOFS intercalibration exercise. The integrated pigment concentrations were computed for depths between 0 and $150 \mathrm{~m}$.

\section{b. Calculations deduced from pigment concentrations}

In order to evaluate the contribution of the different phytoplankton groups to the chl $a$ biomass, we used the ratio of chl $a$ /diagnostic pigment as reported in Table 1 . To take into consideration 19'-butanoyloxyfucoxanthin (19'-BF) containing nanoflagellates (which are often neglected by chemotaxonomical studies), we assumed that the valte of 0.75 which is found for the ratio chl $a / 19^{\prime}$-hexanoyloxyfucoxanthin $\left(19^{\prime}-\mathrm{HF}\right.$ ) in prymnesiophytes (Barlow et al., 1993 [0.67]; Everitt et al., 1990 [0.8]) is also valid for the ratio chl $a / 19^{\prime}-\mathrm{BF}$ in chrysophytes.

The respective contribution of each taxonomic group to the primary production can be calculated from the pigment composition, if the average specific carbon $/ \mathrm{chl} a$ ratios and growth rates are known for each taxonomic group. Table 1 gives the average carbon/chl $a$ (g:g) ratio and growth rate $\left(\mathrm{d}^{-1}\right)$ for the different phytoplanktonic taxa observed in this study.

\section{c. Calibration of the fluorescence signal}

Two methods were tested in order to calibrate, in chlorophyll $a$ equivalent, the in vivo fluorescence signal given by the Sea-Tech fluorometer mounted on the CTDrosette assembly: HPLC (see above) and the classical fluorescence method performed on methanol extracts. The calibration was better using fluorescence technique than HPLC. Although the evaluation of the cause of such differences between both calibrations is not within the scope of the present paper, it is nevertheless 


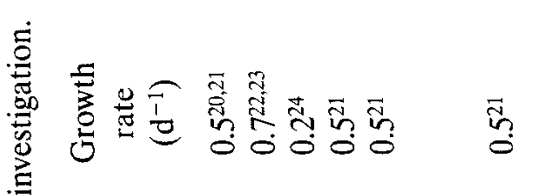
.

学

.

气ั

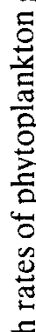

产

ซี

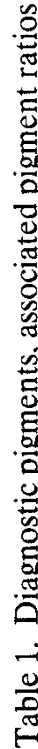

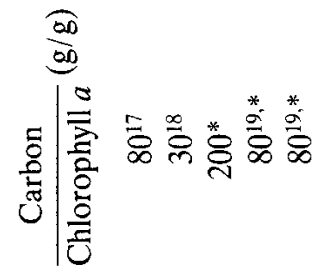

$\stackrel{*}{\infty}$

|

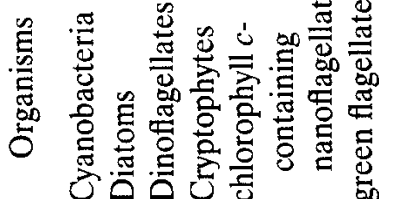

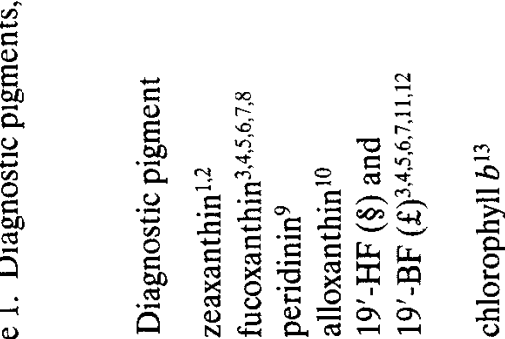

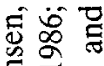

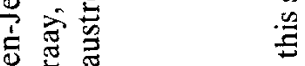

运

$\exists$

के

迄客㣽

च

उं 0

ธ

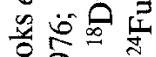

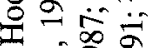

के

$\infty$ व

둘을

运安

$\overrightarrow{\mathrm{v}}=$ व

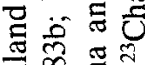

当学

商

范客通

$\circ \stackrel{9}{9}=$

(2)

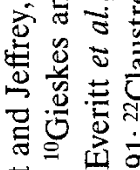

回票市

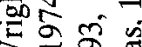

3 ने

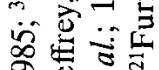

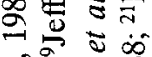

ธิँ

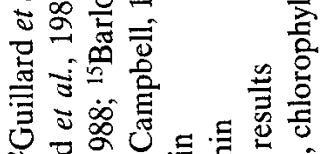

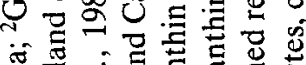

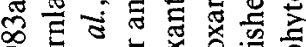

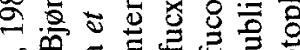

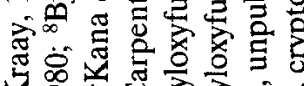

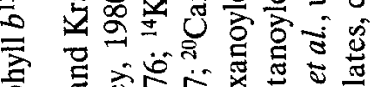

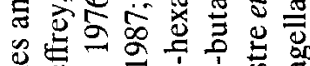
कृ

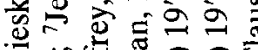

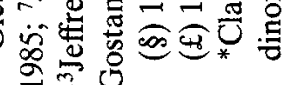


noteworthy that phytoplankton accessory pigments, which may affect the overall in vivo fluorescence signal, were markedly different according to sites (see below). Since HPLC discriminates between these pigments while both fluorescence techniques do not, such a discrepancy in calibrations is not surprising. Therefore, for all synoptic descriptions (leg A) of biomass distributions by means of in vivo fluorescence we use the best calibration which we refer to as chl $a_{f}$ while other detailed investigations (leg B) refer to true chl $a$ (HPLC).

\section{Results}

\section{a. Location of the jet and its overall physico-chemical and biological features}

The main circulation at the synoptic scale can be summarized by the dynamic height of the surface relative to $400 \mathrm{db}$ (Fig. 2A), a level where the mean flow is very weak (Prieur et al., 1993). A narrow jet-front was found, flowing approximately eastwards near $36 \mathrm{~N}$, as seen by the sharp gradient of the surface topography. An anticyclonic structure was found south of the jet and named Atlantic Anticyclonic Gyre (AAG) by Prieur et al. (1993). The other main dynamic structures were found south of Cartagena, as a $60 \mathrm{~km}$-wide anticyclonic eddy (CAF) and south of Almeria as a small surface cyclonic eddy (ACE). The integrated fluorescence distribution (Fig. 2B) reveals the enhanced biomass in the jet frontal area. Excluding the stations of the ACE, all the stations with biomass content over $55 \mathrm{mg} \mathrm{chl} a_{f} \mathrm{~m}^{-2}$ (value corresponding to the mean of the 83 stations investigated during leg $\mathrm{A}$ ) were all inside the jet area. The value of the integrated fluorescence maximum recorded on the frontal area was $100 \mathrm{mg} \mathrm{chl} a_{f} \mathrm{~m}^{-2}$. The sampling network for the general survey was conducted with an $11 \mathrm{~km}$ interval between stations in the transverse jet direction and $20 \mathrm{~km}$ in the along jet direction. The internal radius of deformation being close to $15 \mathrm{~km}$, the important mesoscale features have necessarily been investigated by such a sampling network. However, if one considers the small features of the density and biomass fields, the sampling could have been insufficient in ascertaining the influence of the secondary circulation of the jet frontal zone.

Tow-yo sections allowed us to resolve, on a small scale, the biomass structures in addition to the density and current fields, as shown for one section (Fig. 3). The density field (0-350 m, Fig. 3A) is mainly influenced by the strong pycnocline, between 27.5 and 28.5 isopycnals, which forms the interface between the Atlantic and Mediterranean waters. The distance between the two isolines, while having some variability ( $\min , 40 \mathrm{~m}$; $\max , 60 \mathrm{~m}$ ), remained close to $50 \mathrm{~m}$. The top of this interface is close to $50 \mathrm{~m}$ for the northern (Mediterranean) part of the section and as deep as $150 \mathrm{~m}$ for the southern (Atlantic) part. This strong slope of the interface creates the jet (Fig. 2A), whose frontal aspect is emphasized in a cross-frontal density profile at $100 \mathrm{~m}$ depth (Fig. 3E). A velocity profile at $30 \mathrm{~m}$ (Fig. 3B) showed that the maximum of current was directed eastwards at $42 \mathrm{~km}$ from the transect start point, where the 27 isopycnal runs to the surface. This jet is therefore strongly associated 


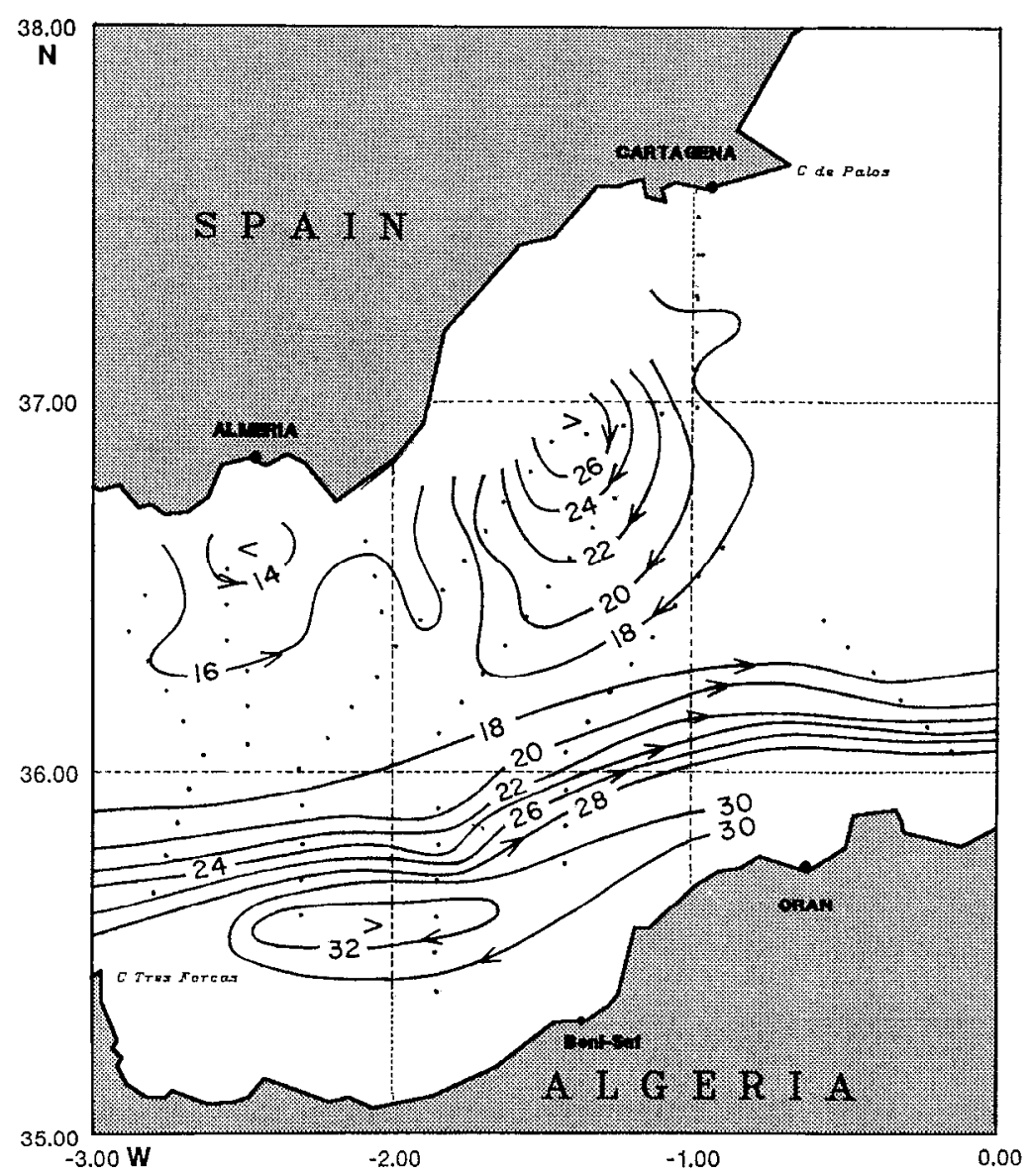

Figure 2. Results from the synoptic survey of leg A. (A) Dynamic topography of the surface relative to the $400 \mathrm{dbar}$ level. (B) map of the integrated chlorophyll fluorescence (one unit of fluorescence is converted to $1.13 \mathrm{mg} \mathrm{chl} a_{f} \mathrm{~m}^{-3}$ ).

with the horizontal gradient of density as would be expected for a classic geostrophic jet with a thermal wind balance of forces. The horizontal ageostrophic current velocities were no more than $20 \mathrm{~cm} \mathrm{~s}$.

A layer of biomass maximum ( $\mathrm{chl} a_{f}, \mathrm{Fig} .3 \mathrm{C}$ ) predominates at $50 \mathrm{~m}$, in particular at the extremities and at the middle of the transect. This overall description has, however, two noticeable exceptions: (1) a lack of biomass at 25 and $50 \mathrm{~km}$ and (2) a lift of the maximum of biomass along the 27 isopycnal inside the core of the jet. Moreover, the core of the jet is characterized by two chl $a$ biomass patches (evidenced by heavy shading, Fig. 3C) located at different isopycnals on each side of the current maximum.

Table 2 presents the general hydrographic and physical features at each of the 6 


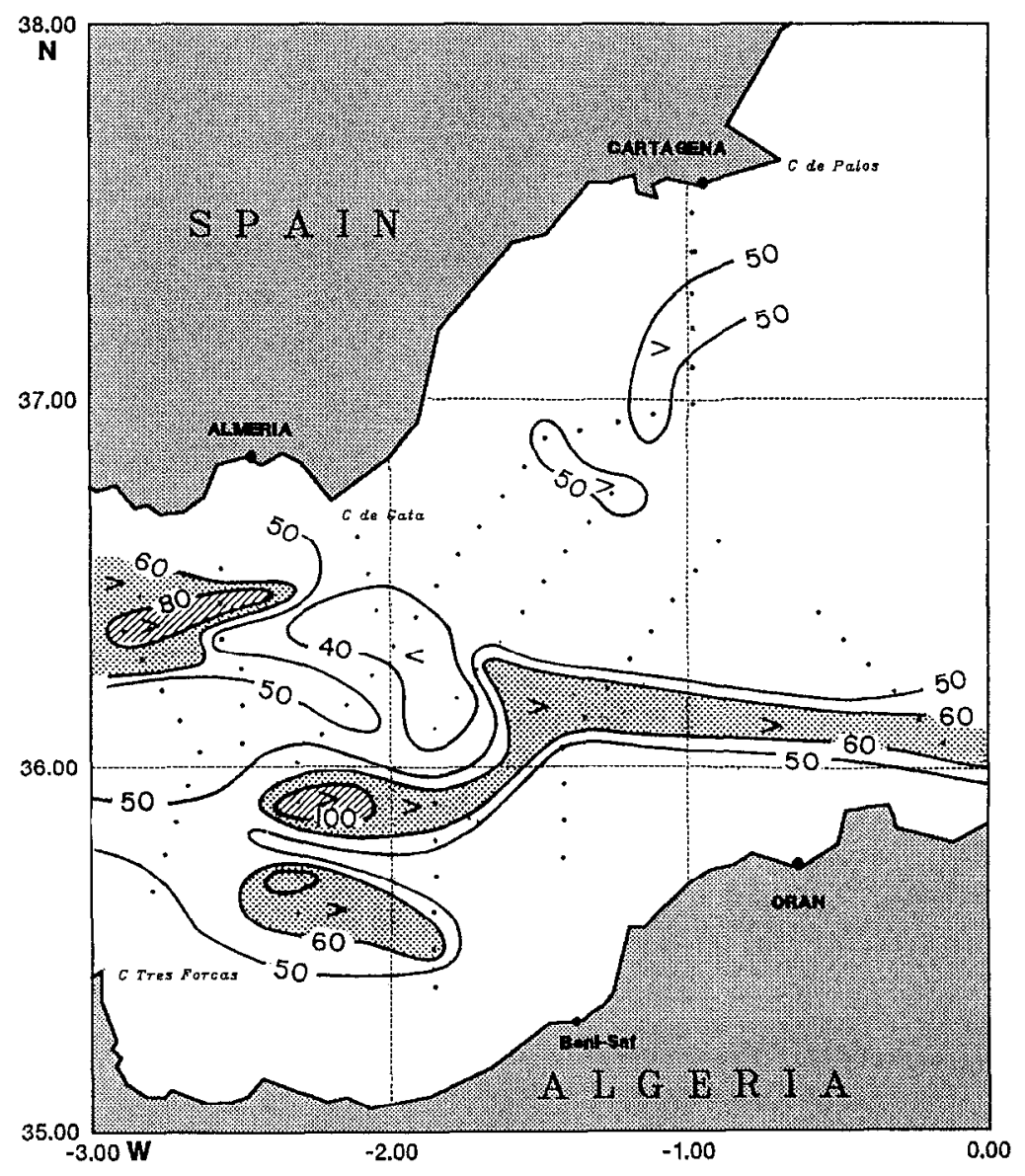

Figure 2. (Continued)

sites according to a cross jet position (Fig. 3E). For a proper characterization of the site location relative to the jet, nonambiguous terminology would be (in the northern hemisphere) cyclonic and anticyclonic sides by reference to the relative vorticity. Nevertheless, in our discussion we will refer to the left (cyclonic, heavy waters) and right (anticyclonic, light waters) sides by reference to the jet flow direction. Moreover, the sites located outside the jet (Table 2, sites 2 and 3) will be also named adjacent area.

The 36 hour trajectories (except for site 4, 24 hours) of the drifters (Fig. 1B) indicate the nature of the investigated sites and their relative positions according to the jet and associated frontal structure (Table 2). The drift recorded at site 2 reveals the northern part of the AAG (Fig. 2A). The large drifts (extending up to $30 \mathrm{~km}$ for 36 hours) recorded at sites 1,5 and 6 clearly demonstrate that these sites are located inside the jet, contrary to site 3 where a very limited drift was recorded (Fig. 2A). The 


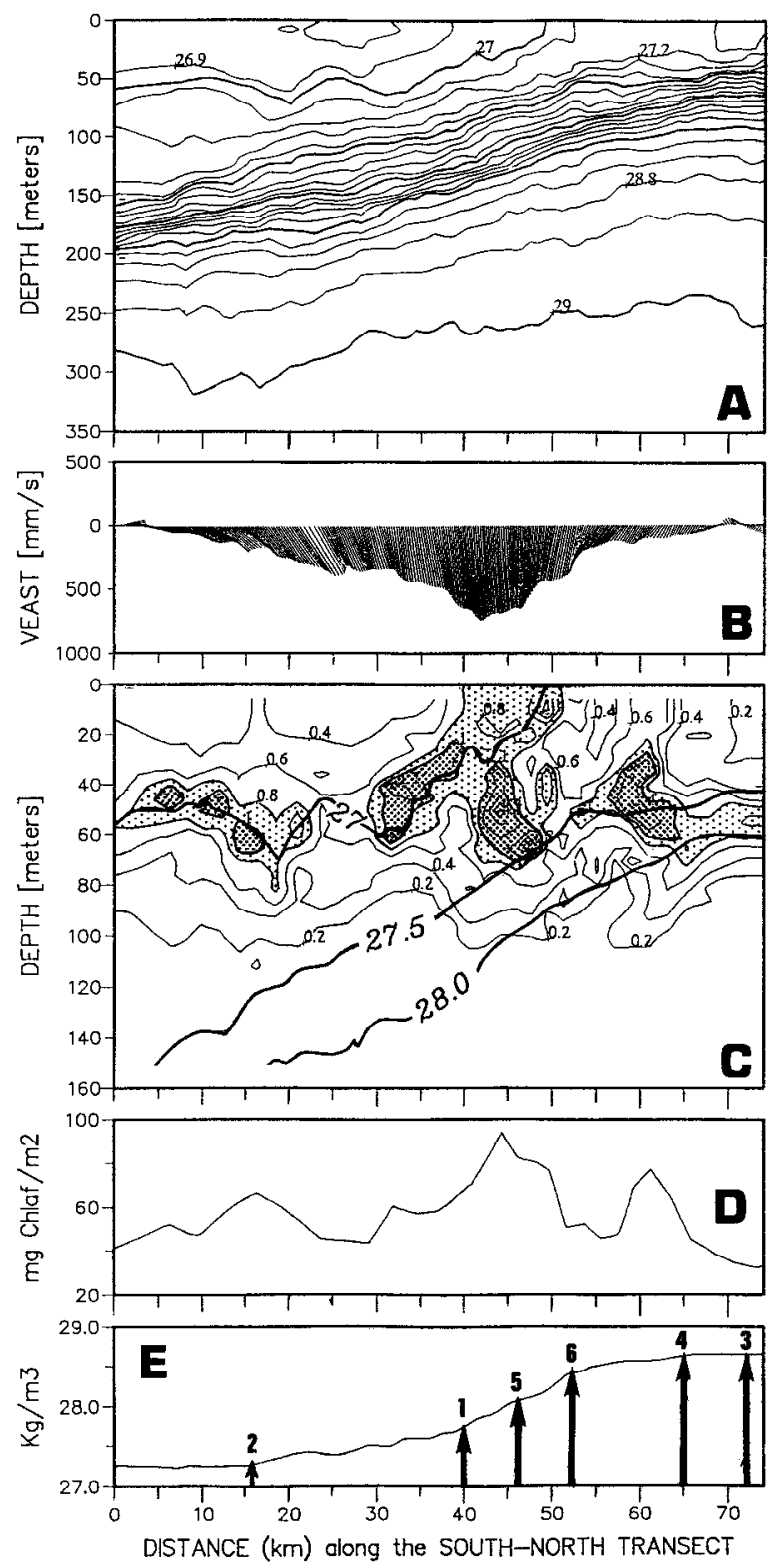

Figure 3. Section Tow-Yo 2 acruss the jet. Date: 6/05/91. Distance on $x$ axis is scaled in km from the starting point of the transect:2.0473W, $35.3241 \mathrm{~N}$. (A) Density field $\left(0.1 \mathrm{~kg} \mathrm{~m}^{-3}\right.$ spacing isolines) of the $350 \mathrm{~m}$ upper layer, as obtained by the CTD casts performed every $1 \mathrm{~km}$. (B) current vector profile at $32 \mathrm{~m}$ as obtained by the bin 3 of $\Lambda \mathrm{DCP}$. Current to east is oriented down, and north is along the $\mathrm{x}$ axis. The east component scale is indicated on the $\mathrm{y}$ axis. The current is plotted each $300 \mathrm{~m}$ of the position of the ship along the transect. Each vector correspond to the mean current of the 28-36 m layer. Maximum of current was approximately to east, $85 \mathrm{~cm} \mathrm{~s}^{-1}$, at $42 \mathrm{~km}$ from the beginning point. (C) Biomass as viewed by chl $a_{f}$ section. The $150 \mathrm{~m}$ upper layer is only shown to enhance details. The 27.0, 27.5 and 28.0 isopycnals are superimposed to enable comparison with the density field (A). Biomasses greater than $0.8 \mathrm{mg} \mathrm{chl} a_{f} \mathrm{~m}^{-3}$ are light shaded and those greater than $1 \mathrm{mg}$ chl $a_{f} \mathrm{~m}^{-3}$ are heavy shaded. (D) Integrated biomasses from the preceding data. (E) Density profile at $100 \mathrm{~m}$ depth. Clearly the front is observed between 40 and $52 \mathrm{~km}$ at this depth. The numbers indicate the equivalent position of the 6 sites investigated during leg $\mathrm{B}$. 


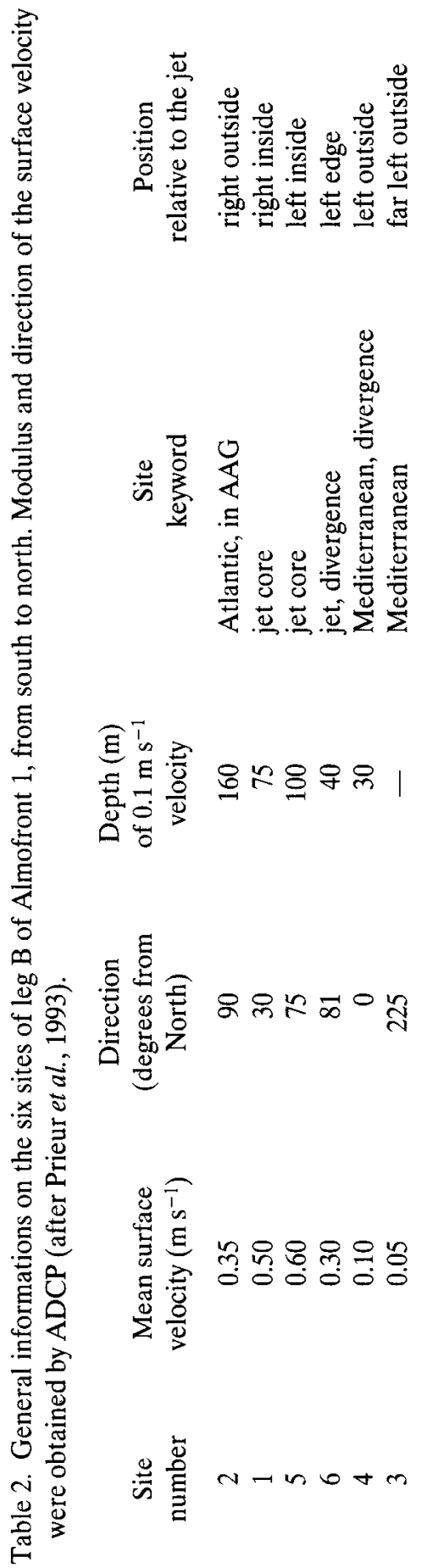


weak northwards drift at site 4 indicates the existence of a divergence on the left side of the jet: therefore the front location is between sites 4 and 6 .

Despite large drifts observed at the sites on the jet core, the density profiles regularily recorded over the 36 hour exploration present a very low variability which is weaker than the variability observed between different sites (Fig. 4). This variability is not obvious when comparing sites 3,4 and 6 which, in a first approximation, appear similar. However, detailed observations show that intermediate waters $(50-150 \mathrm{~m})$ are more dense at sites 4 and 6 than at site 3 , which again reinforces the existence of a divergence near sites 4 and 6 . Differences between sites 4 and 6 mainly reside in surface densities and currents. At site 6 , where Atlantic waters $(S<$ $36.7 \mathrm{psu}$ ) predominate, the currents were up to $30 \mathrm{~cm} \mathrm{~s}^{-1}$, whereas at site 4 , located in Mediterranean waters, currents were below $10 \mathrm{~cm} \mathrm{~s}^{-1}$ (Table 2). This abrupt change in surface currents between both sites (Table 2, Figs. 3B and 3E) is a strong signature of the front.

\section{b. Cross-jet distribution of pigments}

Between the two sites outside the frontal structure, i.e., the Atlantic and Mediterranean one, characterized by integrated values around $20 \mathrm{mg} \mathrm{chl} a \mathrm{~m}^{-2}$ (Fig. 5), all sites present higher levels of integrated chl $a$ content, especially site 1 (average: 63 $\mathrm{mg} \operatorname{chl} a \mathrm{~m}^{-2}$, range: 35 to $92 \mathrm{mg} \mathrm{chl} a \mathrm{~m}^{-2}$ ). Moreover, this chl $a$ content increases from site 4 towards site 1, i.e., from the left to the right side of the jet (Fig. 5). This biomass increase is mainly due to diatoms whose characteristic pigment, fucoxanthin increase markedly from the left to the right side of the jet, except for site 6 (Fig. 5). This observation does not apply for the sum of $19^{\prime}-\mathrm{HF}$ and $19^{\prime}$-BF which are the second pigment in abundance and whose distribution across the frontal gradient does not show any particular tendency (Fig. 5). Besides the nanoflagellate pigments, chlorophyll $b$ (green flagellates), zeaxanthin (cyanobacteria) and peridinin (dinoflagellates) are compounds of relative minor importance (Fig. 5). The variations in peridinin according to the frontal gradient are similar to those of fucoxanthin and chl $a$, but different from chlorophyll $b$ and zeaxanthin. The results for alloxanthin are not presented here since the integrated concentrations of this pigment never exceed $0.4 \mathrm{mg} \mathrm{m}^{-2}$.

The phaeopigments and chlorophyllids (Fig. 6) are typically associated with the jet and their distributions follow that of fucoxanthin (Fig. 5). The maximum integrated concentration of degradation pigments was seen at site 1 , where the maximum of fucoxanthin occurs: about $8 \mathrm{mg} \mathrm{m}^{-2}$ for chlorophyllids as well as phaeopigments. The ratio of these degradation products to chl $a$ (Fig. 6) shows clearly that the vegetal material is more degraded at the frontal site 1 than at the adjacent areas (sites 2 and 3 ). Site 4 , although located at the left of site 6 and closer to site 3 , present higher levels for both ratios.

Table 3 shows the respective contribution of each taxonomic group (as estimated 


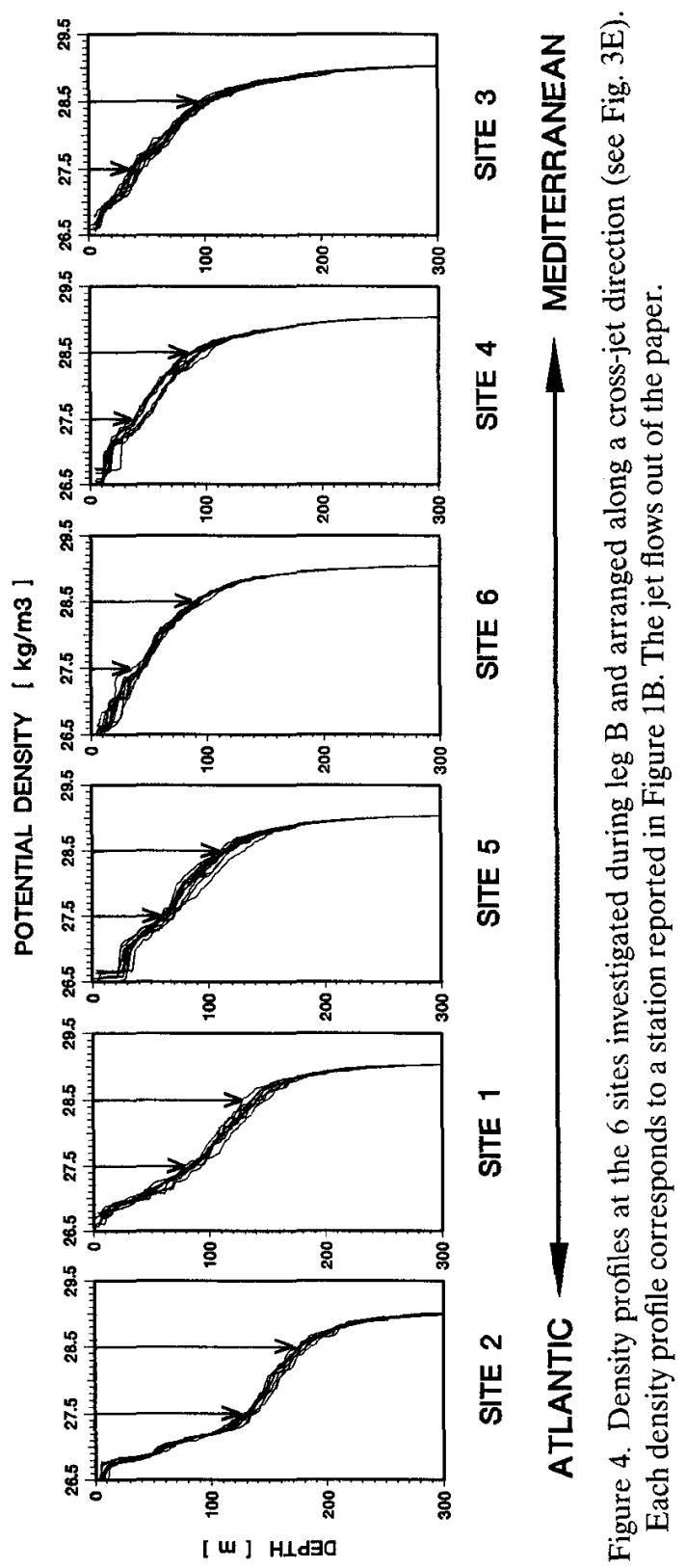



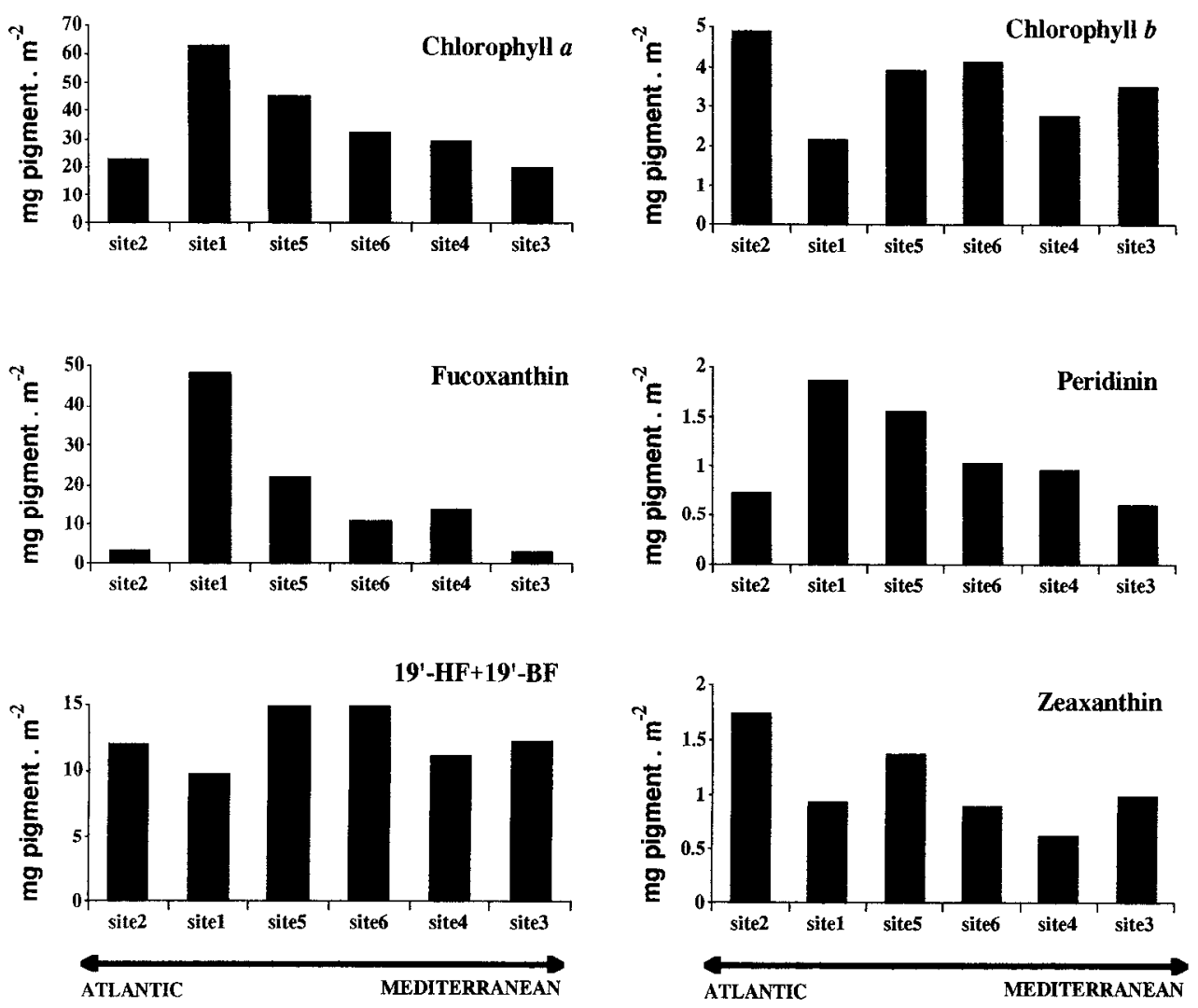

Figure 5. Horizontal distribution of the integrated concentrations of selected diagnostic pigments at the 6 sites investigated during leg $\mathrm{B}$ and arranged along a cross-jet direction (see Fig. 3E). The distribution of alloxanthin (Table 1) is not reported since the concentration of this pigment never exceed $0.4 \mathrm{mg} \mathrm{m}^{-2}$. The jet flows out of the paper.

from pigment ratios, Table 1) to the chl $a$ biomass: diatoms contribute up to $76 \%$ of the chl $a$ biomass at site 1 and about $20 \%$ at sites 2 and 3 . On the contrary flagellates (dinoflagellates, cryptophytes, green algae and 19'-BF, 19'-HF containing cells) dominate at the adjacent area where they contribute to about $60 \%$ of the chl $a$ biomass. The contribution of cyanobacteria is significantly higher at these sites (contribution greater than 10\%) than at the jet sites. The comparison between measured and calculated chl $a$ concentrations (Table 3 ) emphasizes the accuracy of the chl $a$ /diagnostic pigment ratio (Table 1). Nevertheless, the calculation led to a slight overestimation of the concentrations, especially for the frontal site. This is because diagnostic pigment markers, from which the calculation is deduced, are not only associated with healthy chl $a$-containing cells but also with senescent- or grazing-degraded cells. The calculated chl $a$ shows, therefore, a better correlation 

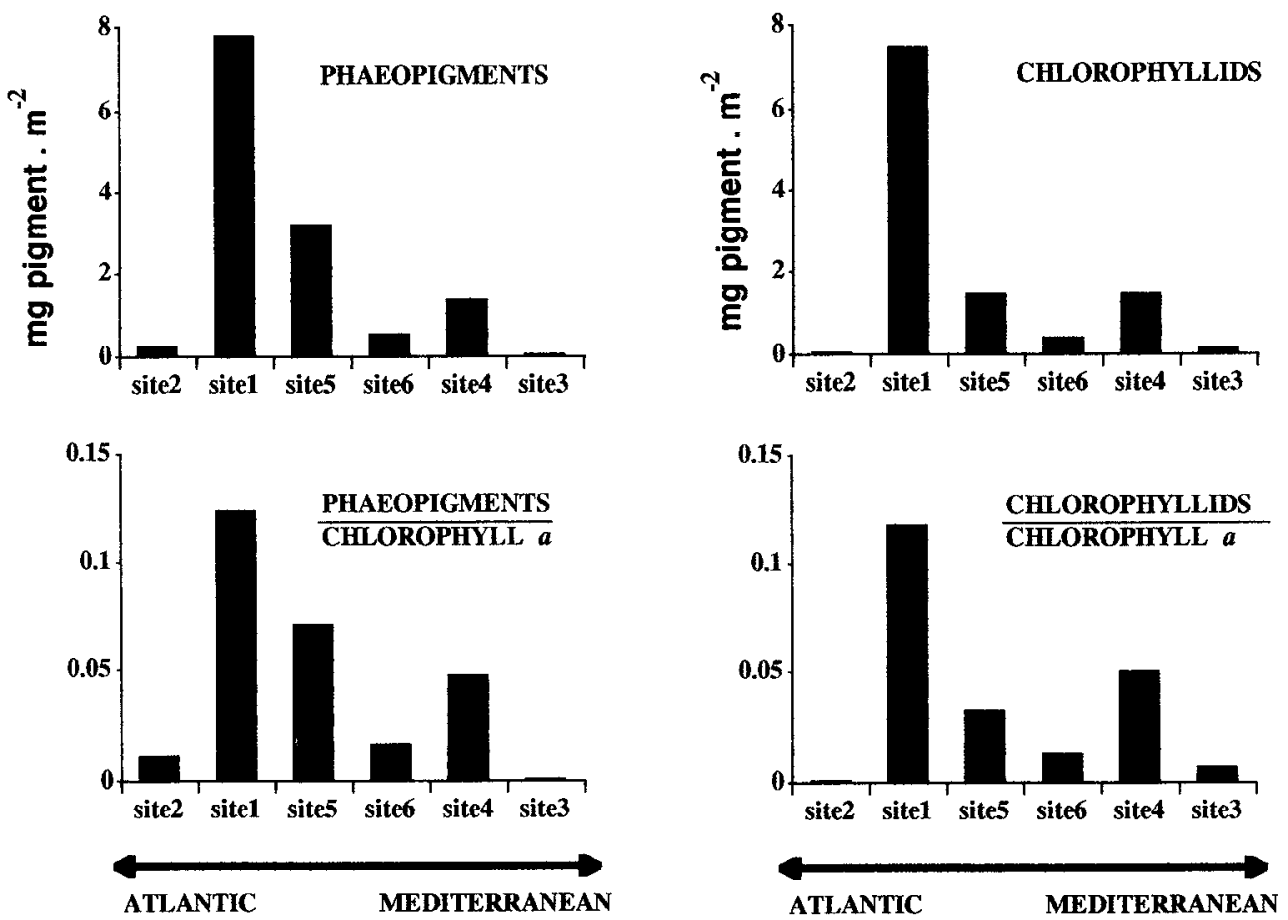

Figure 6. Horizontal distribution of phaeopigments, chlorophyllids and associated ratios at the 6 sites investigated during leg $\mathrm{B}$ and arranged along a cross-jet direction (see Fig. 3E). The jet flows out of the paper.

with the sum of all chloropigments (chl $a$, phaeopigments and chlorophyllids) than with chl $a$ alone (Table 3).

\section{c. Verttcal distribution of pigments}

Chlorophyll $a$. Figure 7A shows the vertical distribution of chl $a$ along the frontal gradient. The frontal sites 1 and 5 are characterized by strong variability of the chl $a$ distribution and by a lack of a clear chl $a$ maximum for the 4 successive profiles over 36 hours. The highest chl $a$ concentration was recorded at site $1\left(1.3 \mathrm{mg} \operatorname{chl} a \mathrm{~m}^{-3}\right)$. In contrast to these typical frontal sites, the variability for replicate profiles is weak at the adjacent sites 2 and 3 and at the sites located to the left side of the jet (4 and 6 ). A $\mathrm{chl} a$ maximum was clearly established around $60 \mathrm{~m}$ at sites 3,4 and 6 (and slightly shoaler at the Atlantic site 2). Where the maximum value is near $0.7 \mathrm{mg} \operatorname{chl} a \cdot \mathrm{m}^{-3}$ for the left side sites 4 and 6 , this value is near $0.5 \mathrm{mg} \mathrm{chl} a \mathrm{~m}^{-3}$ at site 2 and $0.4 \mathrm{mg} \mathrm{chl}$ $a \mathrm{~m}^{-3}$ at site 3 . At site 3 , the profile is broader than at other sites still with a significant $\operatorname{chl} a$ biomass below the maximum ( $\left.0.1 \mathrm{mg} \operatorname{chl} a \mathrm{~m}^{-3}\right)$.

Qualitative distribution. The respective vertical contributions of the three main phytoplankton groups (diatoms, cyanobacteria and flagellates) along the frontal 
Table 3. Contribution (as percentage of the total) of the different phytoplankton groups to the chl $a$ biomass at the six sites investigated during leg $\mathrm{B}$. The chl $a$ concentration associated with each taxonomic group is estimated as the product of the diagnostic pigment concentration by the chl $a$ /diagnostic pigment ratio (Table 1). The sum of these calculated chl $a$ concentrations is reported onto column $4(\Sigma \mathrm{chl} a)$ and compared with measured chl $a$ (column 5) and the sum of the different chloropigment-types (chl $a+$ phaeopigments + chlorophyllids, column 6).

\begin{tabular}{|c|c|c|}
\hline $\begin{array}{l}\text { agellates* } \\
(\%)\end{array}$ & $\begin{array}{c}\text { Cyanobacteria } \\
(\%)\end{array}$ & $\begin{array}{c}\text { Diatoms } \\
(\%)\end{array}$ \\
\hline
\end{tabular}

$\begin{array}{llrllll}\text { Site } 2 & 65 & 16 & 19 & 22 & 23 & 23 \\ \text { Site } 1 & 22 & 2 & 76 & 76 & 63 & 78 \\ \text { Site } 5 & 37 & 6 & 57 & 48 & 45 & 50 \\ \text { Site } 6 & 51 & 6 & 43 & 31 & 32 & 33 \\ \text { Site } 4 & 40 & 4 & 56 & 31 & 29 & 32 \\ \text { Site 3 } & 69 & 11 & 20 & 19 & 20 & 20\end{array}$

${ }^{*}$ Dinoflagellates, cryptophytes, $19^{\prime}$-HF and $19^{\prime}$-BF-containing flagellates and green flagellates (see Table 1).

gradient was estimated using the chl $a$ /diagnostic pigment ratio approach (Fig. 7B). The pigment ratios were assumed to be stable with depth which implicitly neglects the effect of photo-adaptation or nutrient status of algae. Nevertheless, these procedures allow elucidation of the main qualitative differences in the phytoplankton community despite the large quantitative variability of chl $a$ biomass between and within sites. Flagellates predominate over diatoms only at sites 2 and 3, where they represent from 50 to $80 \%$ of the biomass through the water column. These sites are also characterized by an important contribution of cyanobacteria at surface (up to $50 \%$ ). In contrast, at site 1 , cyanobacteria are lacking and diatoms predominate over flagellates throughout the water column considered (from 50 to $90 \%$ of the chl $a$ biomass). Despite the high variability of chl $a$ biomass at this site 1 (Fig. 7A), the qualitative variability is low, i.e., the phytoplankton community is stable (Fig. 7B). Other sites $(4,5$ and 6$)$ present intermediate phytoplankton assemblages. Diatoms always predominate over flagellates at depth but the degree of dominance depends on the site. In particular, at site 6 diatoms predominate at the surface, flagellates from 15 to $60 \mathrm{~m}$ and diatoms again below $60 \mathrm{~m}$. Site 5 has the highest variability which includes a significant proportion of cyanobacteria at surface.

\section{Discussion}

\section{a. Biomass distribution in relation to the frontal structure}

The most cvident result of the present investigation is the presence of a zonc of enhanced autotrophic biomass between two zones of low biomass (typical Atlantic and Mediterranean waters), associated with the inflowing Atlantic water jet (Figs. 2 and 3). Such biomass accumulation associated with ergoclines is a phenomenon 

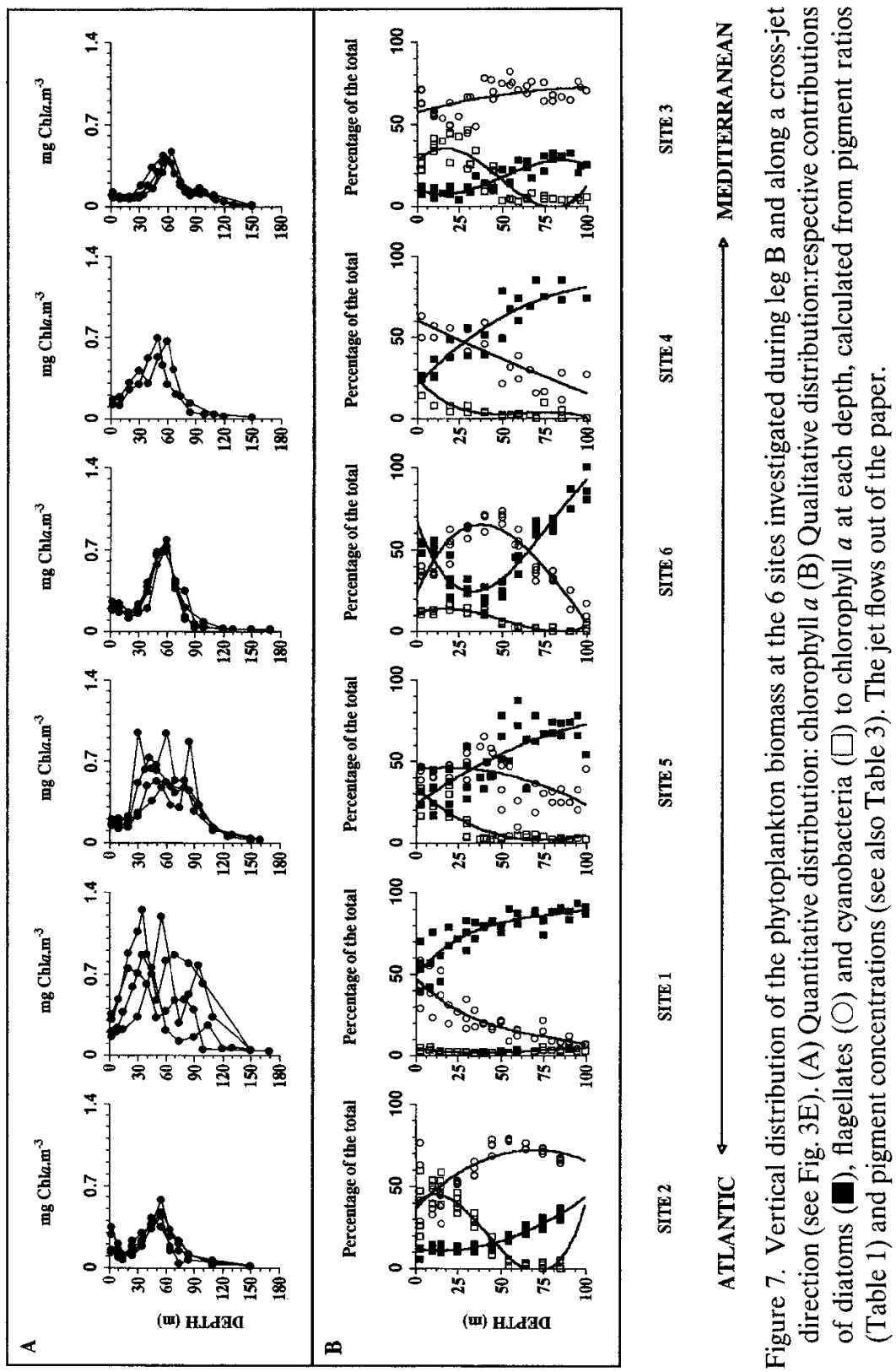
already described for tidal fronts (Pingree et al., 1975; Simpson et al., 1979), topographic fronts (Simpson et al., 1982; Townsend et al., 1983), wind-driven upwellings (Dengler, 1985; Traganza et al., 1987) or plume fronts (Coste et al., 1977). However, in open waters, and in particular for the Mediterranean Sea, well known for its oligotrophic waters, data are more scarce due to the difficulty of applying sampling strategies adapted to the study of such mesoscale structures. For the Almeria-Oran front, Gould and Wiesenburg (1990) reported exceptionally high values of chl $a$ biomass (more than $200 \mathrm{mg} \mathrm{chl} a \mathrm{~m}^{-2}$ ) confined to a very thin layer ( $23 \mathrm{mg} \mathrm{chl} a \mathrm{~m}^{-3}$ at $54 \mathrm{~m}$ ). Their observations were made in November 1987 when the jet ran in a northwest southeast direction. Lohrenz et al. (1988a), working in spring in the same area [the jet showing the same direction as in Gould and Wiesenburg (1990)] and in the Algerian current found very few differences between typical Mediterranean (29 $\mathrm{mg} \mathrm{chl} a \mathrm{~m}^{-2}$ ) and Atlantic or frontal waters (35 $\mathrm{mg} \mathrm{chl} a \mathrm{~m}^{-2}$ ). On the contrary, our results, obtained during the same season as those reported by Lohrenz et al. (1988a) show large differences between the typical frontal area (up to $100 \mathrm{mg} \mathrm{chl} a \mathrm{~m}^{-2}$, for the sum chlorophyllid and chl a) and the Atlantic and Mediterranean waters ( $20 \mathrm{mg} \mathrm{chl} a \mathrm{~m}^{-2}$ ). These observations may suggest that the frontal system and the associated biological properties (seen by phytoplankton biomass) are highly variable from one year to another. On the other hand, the distance between stations in the investigation of Lohrenz et al. (1988a) was larger than in the present study, so that the important biological signatures of the frontal system may have been missed by their sampling network. The spatio-temporal scales of observation used in this study suggest that the frontal system associated with the jet is quite stable. (1) Temporally, it is noteworthy that the biomass maximum (100 $\mathrm{mg}$ chl $a \mathrm{~m}^{-2}$ ) was observed during both leg A (station 24) and leg B (some stations of site 1). These large biomasses were, in both cases, associated with the jet core (more likely to its right side). (2) Spatially, the observations made in the cross-jet direction for tow-yo section 2 (Fig. 3) were similar to the other tow-yos (Fig. 1A), in particular: (i) comparable maxima (100 $\mathrm{mg} \mathrm{chl} a_{f} \mathrm{~m}^{-2}$, Figure 3D). (ii) presence of two biomass minima at each side of the velocity maximum (Fig. 3C). (iii) Shoaling of the biomass corresponding to the 27 isopycnal. The cross-jet physical and biological features, therefore, appear to be identical and reproducible along the front. Consequently, these observations reinforce the significance and reproductibility of the observations conducted during leg B.

For most of the open-ocean area, regional statistics allow a reasonable characterization of the relationships between surface and integrated chl $a$ concentrations (e.g. Morel and Berthon, 1989). Lohrenz et al. (1988a) reported a significant correlation $(p<0.01)$ between surface and integrated chl a concentrations for the AlmeriaOran front and the Algerian current. However, from the present investigation, when plotting surface against integrated chl $a$ concentration (Fig. 8), such a statistical relationship cannot be inferred. Stations with surface values greater than $0.6 \mathrm{mg} \operatorname{chl} a$ 


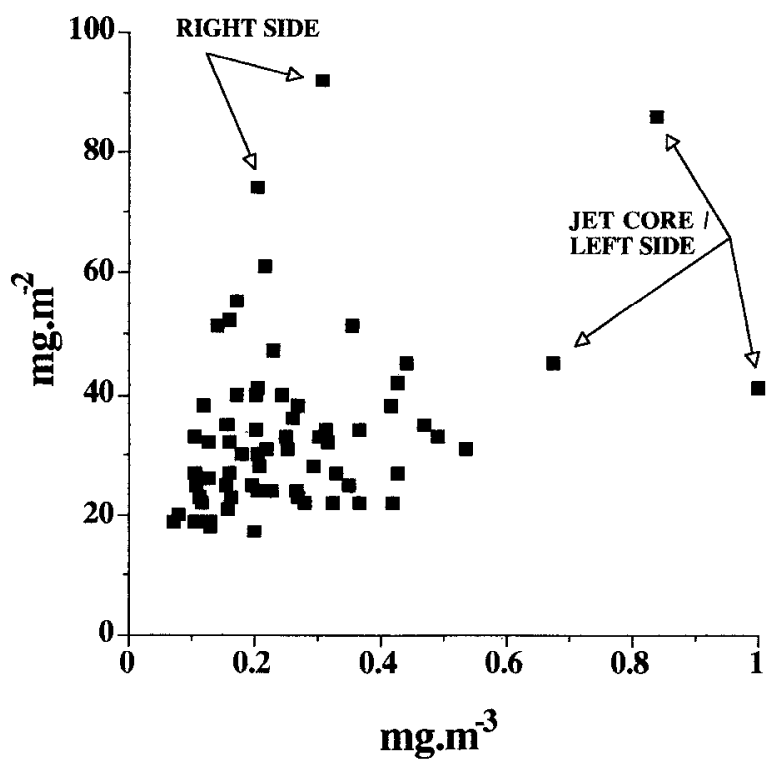

Figure 8. Plot of the relation between surface and integrated chlorophyll $a$ content for all stations investigated during legs $\mathrm{A}$ and $\mathrm{B}$ of Almofront 1 .

$\mathrm{m}^{-3}$ or with integrated values greater than $60 \mathrm{mg} \mathrm{chl} a \mathrm{~m}^{-2}$ (Fig. 8) are typical of frontal stations which attests to the large variability at such sites. The average surface chl $a$ concentration at site 2 (Atlantic) is 2.5 fold higher than that at site 3 (Mediterranean), yet the integrated biomasses at both sites are identical; in addition, sites 1 (frontal) and 2 (Atlantic) have nearly the same surface chl $a$ concentration although the integrated biomass at site 1 is 3 fold higher than at site 2 . The difference between the data in Lohrenz et al. (1988a) and our results mainly resides in the fact that we observed a much stronger gradient than they did. Such remarks demonstrate that the singularities of a frontal area make it difficult to establish empirical relationships useful for a synoptic satellite description (Franks, 1992b). Our present knowledge of phytoplankton distributions and associated ocean color for such dynamic areas of the ocean is relatively scarce. Further research is necessary, particularly to define the important scales of observation which will allow accurate extrapolations, using new algorithms.

\section{b. Phytoplankton assemblage in relation to the frontal structure}

Horizontal patterns. Franks (1992a,b) clearly reviewed the problem of enhanced biomass at fronts: accumulation or locally enhanced production? Using a model of steady, 2-dimensional cross-frontal circulation, Franks (1992a) concluded that accumulation through purely physical processes is not negligible. Our work shows that the enhanced biomass zone is diatom-dominated and completely different from that of 
the adjacent, flagellates- and cyanobacteria-dominated areas. The magnitude of this phytoplankton (diatom) development is similar to that recorded in other well-known upwelling areas, which suggests that nutrient fluxes into the photic layer are high and supported by advective and diffusive processes. These processes may involve enhanced mixing due to local uptake, enhanced diffusion driven by friction at the front, and the ageostrophic cross-frontal circulation whose existence and influence on the biological dynamics have recently been documented for such open-ocean front systems (Boucher et al., 1987; Franks, 1992b). We suggest here that this cross-frontal circulation and its interaction with other diffusing mixing processes accounts for most of the unusual biological and ecological properties of the frontal system studied. The cross-frontal circulation relies on the existence of one or two closed vertical circulation loops (Boucher et al., 1987; Franks, 1992b): while upwelling of dense nutrient rich waters takes place on the left side of the jet, convergence and downwelling occur on the right side, the transit time of those waters in the euphotic zone being sufficiently long for phytoplankton growth. Although physical data do not allow us to fully characterize such an advective process, the distribution of the biological properties tend nevertheless to support this basic circulation loop hypothesis. (1) The chl $a$ biomass increases from the left to the right side of the jet (Fig. 5), i.e. from the dense towards the lighter waters. Site 1, which is located at the right side, has the highest integrated chl $a$ biomass. Assuming constant loss terms (grazing, sinking and diffusion), this increase in biomass may certainly arise from enhanced primary production due to nutrient supply. (2) The phytoplankton community change along the cross-frontal gradient with an increasing diatom contribution from the left to the right side of the jet (Figs. 6 and 7B). Diatoms are considered to be typical of upwelling areas, sufficiently opportunistic to take advantage of nutrient enrichment (Fogg, 1991). Our observation of a "diatom oasis" within two oligotrophic zones was not reported by Lohrenz et al. (1988a) who found, while investigating a similar area, that phytoplankton populations were dominated by the ubiquitous prymnesiophyte Emiliania huxleyi, particularly in the frontal area and modified Atlantic waters. In their study, diatoms were never dominant, as opposed to our results. Such fundamental differences between both investigations, performed in the same area and season, point out the changing nature of nutrient enrichment by the cross-frontal circulation. The formation of meanders along the jet inflow could be at the origin of the strength of the secondary circulation and associated upwelling, as has been documented for the Gulf Stream by Bower and Rossby (1989) and Arnone et al. (1990).

In comparison to diatoms, the flagellate biomass appears to be stable (coefficient of variation of $17 \%$ for all sites for flagellate pigments compared to $100 \%$ for diatoms). It seems that the frontal system does not particularly affect this flagellate community. Rather, the front appears to have been a local event causing enhanced diatom growth over a continuum of flagellates, ubiquitous in Atlantic and Mediterra- 

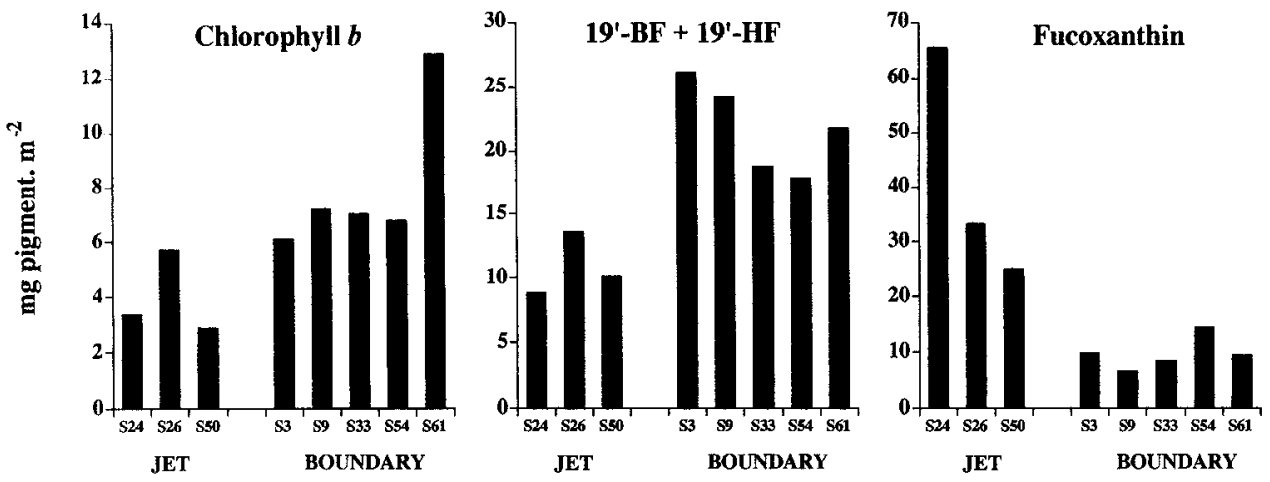

Figure 9. Integrated pigment content for the 8 stations of the leg A presenting integrated chlorophyll $a$ content greater than $40 \mathrm{mg} \mathrm{m}^{-2}$.

nean waters, as well as on the front itself. These observations agree with the conclusions of Fogg (1991) who suggests that small phytoplankton (which include flagellates) cannot reach high biomasses, since biomass elevation actuates a feedback mechanism favoring the predators and which may finally enhance the rate of primary production rather than biomass accumulation.

Nevertheless, some observations conducted during leg A did not agree with a constant flagellate biomass. Among the 8 stations whose chl $a$ content is greater than $40 \mathrm{mg} \mathrm{chl} a \mathrm{~m}^{-2}$ (Fig. 9), 3 of them, located inside the jet core, present the expected high fucoxanthin content whereas the five others, located onto boundaries (and in CAE), are dominated by flagellate pigments whose concentrations are the highest recorded during the whole study (Fig. 9 vs. Fig. 5). Such high flagellate biomasses at specific station locations suggests the presence of particular phytoplankton communities, typical of the transient situation associated with nutrient enrichment of oligotrophic-mesotrophic Atlantic waters in the front. The phytoplankton community present before the nutrient enrichment is most likely that observed for typical Atlantic waters, i.e., flagellate dominated with a weak diatom contribution (site 2, Figs. 5 and 7B). Although diatoms initially grow faster than flagellates as a consequence of nutrient enrichment (Fogg, 1991), for a short period of time, the biomass of flagellates will increase (in absolute terms) more significantly than the diatoms, because flagellates dominated the biomass at the beginning of this enrichment. This flagcllate development may also be amplified as secondary production (microbial loop) may be uncoupled for a short time. Whatever the physical/biological interactions at the origin of this paradoxical pattern, our data show the importance and the diversity of transient situations that occur at frontal zones and which require adapted sampling strategies. Moreover, although the jet appears to be a rather stable system at the scales of month $/ \mathrm{km}$, it is noteworthy that transient events exist at smaller scales, whose significance needs to be quantified. 
Vertical patterns. The depth distribution of chl $a$ is much more variable with time at the sites located at the right side of the jet core (sites 1 and 5) than at the other sites (Fig. 7A). Numerous in vivo fluorescence profiles (Videau et al., 1994) confirm these observations as well as the presence, solely at sites 1 and 5 , of a fluorescence peak, a few meters thick and superimposed on the general signal of fluorescence. This patchy biomass distribution is related to the prevalence of diatoms along the frontal gradicnt, and may be the result of association with physical microstructures which locally favor biomass production or accumulation, as reported by Gould and Wiesenburg (1990) for the same area. It may also be due to the formation of millimeter-to centimeter-sized diatom aggregates, as reported earlier for bloom conditions (Kranck and Milligan, 1988; Alldrege and Gotschalk, 1989; Gotschalk and Alldrege, 1989).

The relative proportion of diatoms with depth increases at all sites (except site 6) which may be related to the ability of diatoms to develop close to the nitracline. Concomitantly the flagellate distribution is stable with depth while cyanobacteria, when present, are associated with the top $40 \mathrm{~m}$. The pecularities of site 6 (Fig. 7B), reside (1) in a nonmonotonic distribution of flagellates and diatoms with depth, (2) and in an inverse relationship between the two distributions. Diatoms dominate at the surface (top $15 \mathrm{~m}$ ) and below $60 \mathrm{~m}$ whereas flagellates dominate between 15 and $60 \mathrm{~m}$. This phytoplankton distribution corresponds to the presence of two different water masses. The predominance of diatoms in surface waters is associated with the shoaling of the 27.0 isopycnal in the euphotic zone (Figs. 3C, 3E). Below, the relative diatom maximum corresponds with the dense part of the frontal zone. These observations are supported by the depth distribution of the nitrate/silicate ratio (Fig. 10 ), which is expected to be high when diatoms predominate and grow. High ratio values at the surface are, thus another indication of upwelled deep waters. The vertical distributions of properties at this site, therefore, indicate phenomena which result from the superposition of two different hydrodynamic structures as already shown in Figure 3.

The typical Mediterranean (site 3) and Atlantic (site 2) sites present the strongest differences in hydrologic terms: at the Allantic site, there is a mixed layer between 20 and $50 \mathrm{~m}$ which is not encountered in Mediterranean waters (Fig. 4). The observed phytoplankton community is similar at the two sites: the integrated biomasses are similar (Fig. 5), the chl $a$ maximum is located at nearly the same depth (Fig. 7A) and the depth distributions of the three main phytoplankton groups are also comparable (Fig. 7B). Although the physical forcing is different, the biological responses appear similar for those two sites far away of the frontal structure. Moreover the pigment signature is characteristic of oligotrophic conditions.

One criterion, however, does not meet this observation. The distribution of the $19^{\prime}-\mathrm{BF} / 19^{\prime}-\mathrm{HF}$ ratio is homogeneous with depth at site 2 while it regularly increases from 40 to $80 \mathrm{~m}$ for the typical Mediterranean waters (Fig. 11). This is the sole property we measured that differs in the pigment signatures of typical Atlantic and 


\section{nitrates}

\section{silicates}

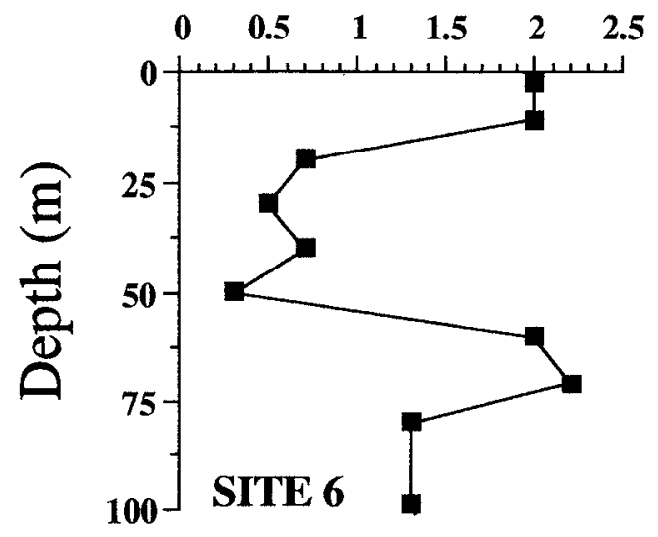

Figure 10. Depth distribution of the nitrate/silicate ratio at site 6 .

Mediterranean waters. The regular increase of this ratio with depth is a rather common feature also observed in the North tropical ocean as well as in a coastal station of the Ligurian Sea (Claustre et al., unpublished results). This cannot be the result of a chromatic adaptation as spectral characteristics of $19^{\prime}$-HF and $19^{\prime}$-BF are identical (Bjørnland et al., 1988, 1989). Such a ratio distribution may rather reflect differences in distribution of $19^{\prime}$-BF containing flagellates (most likely chrysophytes) and $19^{\prime}$-HF containing one (most likely prymnesiophytes): the chrysophyte contribution increases with depth. When typical Mediterranean and Atlantic waters cannot be discriminated according to their relative cyanobacteria, diatom and overall flagellate content, discrimination may be possible according to their prymnesiophyte/ chrysophyte content. Moreover the depth distribution of this criterion appears related to nitrate distribution (Fig. 11), which suggests a nutrient control of the respective distributions of prymnesiophytes and chrysophytes in the water column.

\section{c. From the biomass to production}

Integrated pigment concentrations (Fig. 5) and assumptions about the average carbon/diagnostic pigment ratio and growth rate (Table 1) allow the calculation of specific production associated with each phytoplankton taxon. Figure 12 compares the calculated with the measured integrated primary production (Videau et al., 1994). The best correspondence between measured and calculated values is obtained for the most characteristic sites i.e. the flagellate and cyanobacteria-dominated sites 2 and 3 and the diatom-dominated site 1 . For site $1,67 \%$ of the total production is due to diatoms ( $29 \%$ to flagellates) whereas for site 2 and 3 about $70 \%$ and $15 \%$ are due to flagellates and cyanobacteria, respectively (Table 4). There is a discrepancy 


$$
\text { ○ } \frac{19^{\prime}-\mathrm{BF}}{19^{\prime}-\mathrm{HF}^{-}}
$$

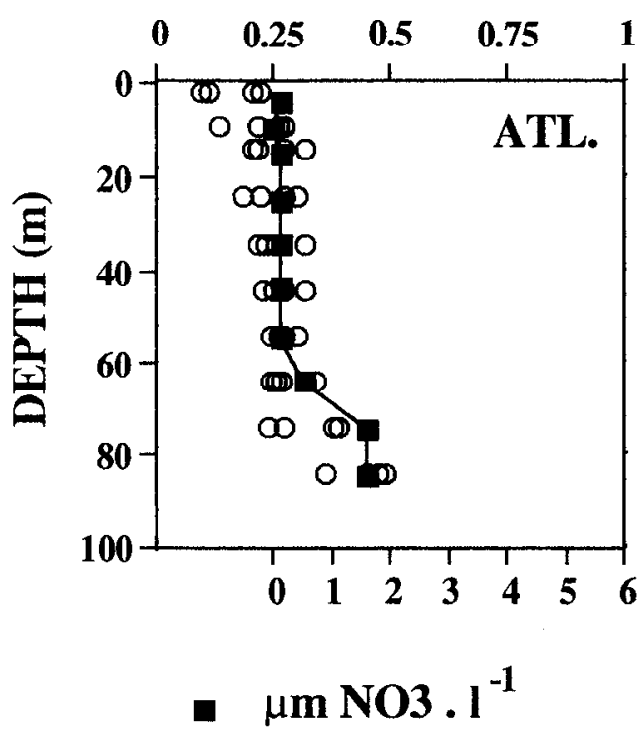

- $\frac{19^{\prime}-\mathrm{BF}}{19^{\prime}-\mathrm{HF}}$

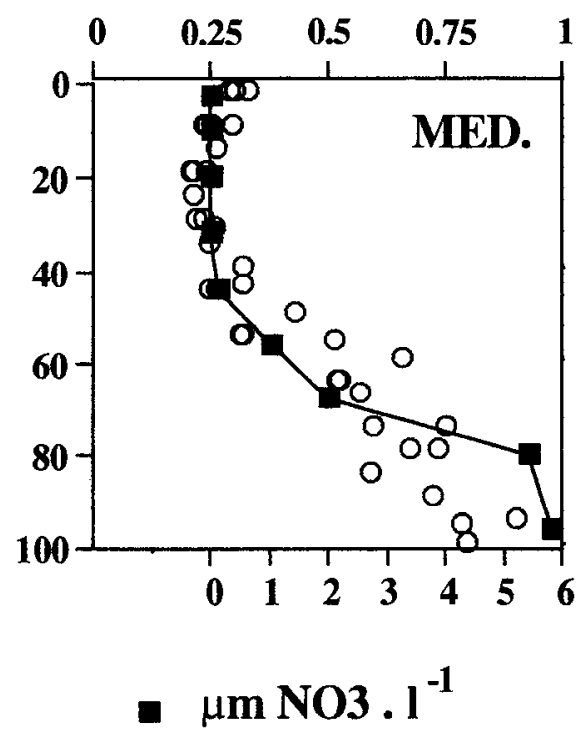

Figure 11. Relation between the distribution of nitrate (closed squares) and the ratio $19^{\prime}-\mathrm{BF} / 19^{\prime}$-HF (open circles) for typical Mediterrannean (site 3) and Atlantic (site 2) waters.

between measured and calculated production for sites 4 and 6 . Calculated productions differ by more than $45 \%$ (underestimation for site 6 and overestimation for site 4) which suggests that the assumptions made about growth rates for these sites are inaccurate. Assimilation ratios for these sites are the most extreme of the present investigation with 17 and $55 \mathrm{mg} \mathrm{C}(\mathrm{mg} \mathrm{chl} a)^{-1} \mathrm{~d}^{-1}$ for sites 4 and 6 , respectively. However, the phytoplankton communities appear to be identical at both sites (Figs. 5 and 7B) implying great differences of physiological states. Site 4 appears to represent a characteristic bloom-end situation (as confirmed by low productivity levels and high level of degradation products when normalized by chl $a$, Fig. 6). In contrast, site 6 , shows characteristics of a bloom beginning (high productivity level and few degradation products). This observation demonstrates that the frontal structure generates small-scale features in which phytoplankton populations are in transient states and exhibit unexpected production rates. The contribution of such areas to the production of a whole basin merits, therefore, more detailed investigation.

\section{d. Fate of the biomass in relation to the frontal structure}

The fate of the phytoplankton biomass, evidenced by phaeopigment and chlorophyllid distributions, presents additional evidence of the response of the biological 


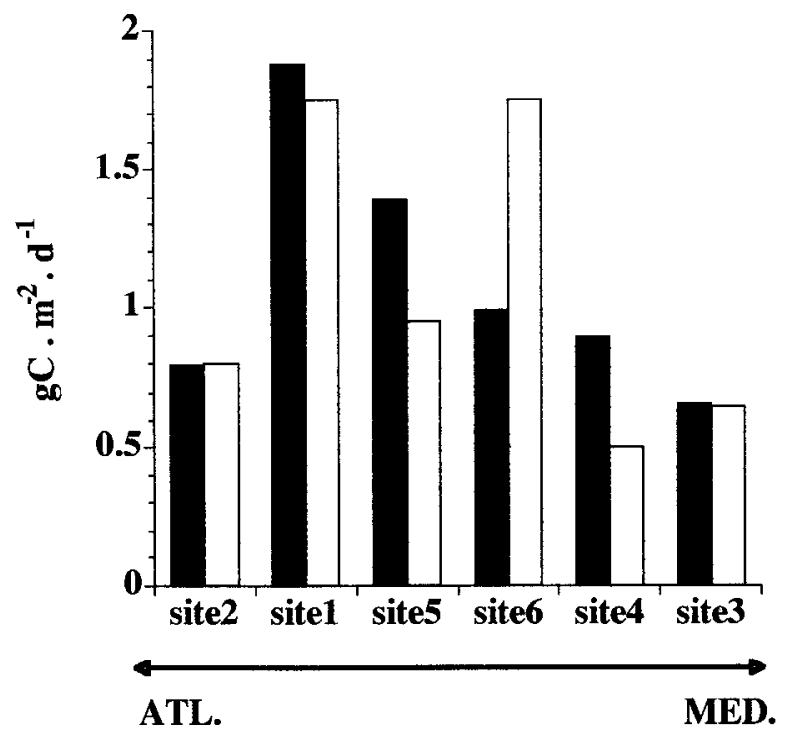

Figure 12. Comparison of measured integrated primary production data (black, Videau et al., 1993) with production rates calculated on the basis of accessory pigment distributions and assumptions on growth rate and carbon/chlorophyll $a$ ratio (white). The jet flows out of the paper.

properties to the mesoscale physical forcing (cross-frontal circulation and associated diffusive processes). The results may be examined in two ways:

(1) The front is characterized by a significant contribution of phaeopigments as compared to oligotrophic adjacent waters. Oligotrophic waters are characterized by the dominance of flagellates (and to a lesser extent cyanobacteria) whose main consumers are the heterotrophs of the microbial loop. It has been supposed that fecal pellets produced by these organisms are so small that they do not sink and their

Table 4. Contribution (as percentage of the total) of the different phytoplankton groups to the integrated production at the six sites investigated during leg B. Specific productions are calculated as the product of chl $a$ associated with each taxonomic group (Table 3 ) by specific carbon/chlorophyll $a$ ratios and by specific growth rates (Table 1).

Flagellates* Cyanobacteria Diatoms

$\begin{array}{llrl}\text { Site2 } & 72 & 17 & 11 \\ \text { Site1 } & 29 & 4 & 67 \\ \text { Site5 } & 50 & 8 & 42 \\ \text { Site6 } & 64 & 7 & 29 \\ \text { Site4 } & 54 & 6 & 40 \\ \text { Site3 } & 75 & 13 & 12\end{array}$

${ }^{*}$ Dinoflagellates, cryptophytes, $19^{\prime}$-HF and $19^{\prime}$-BF-containing flagellates and green flagellates (see Table 1). 
phaeopigment content is photo-oxidized (Soo Hoo and Kiefer, 1982; Welschmeyer and Lorenzen, 1985). Moreover it has been experimentally demonstrated by Klein $e t$ al. (1986) and Barlow et al. (1988), that the organisms of the microbial loop, after ingestion of phototrophic particles, degrade chlorophylls (and carotenoids) into colorless residues not identifiable by HPLC. Both observations explain the lack of phaeopigments described for all oligotrophic areas since the introduction of HPLC (Vernet and Lorenzen, 1987; Herbland, 1988; Ondrusek et al., 1991). On the other hand, for eutrophic conditions where diatoms are predominant, significant contributions of phaeopigments are recorded. The most likely grazers of diatoms, copepods, do not completely degrade phytoplankton pigments so that significant contributions of degradation products can be recorded (Conover et al., 1986; Claustre et al., 1992). Moreover copepod fecal pellets sink rapidly (Komar et al., 1981), preventing their phaeopigment content from being photo-oxidized. Therefore, the presence vs absence of phaeopigments (as properly analyzed by HPLC) is a good indicator of the type of ecosystem. Phaeopigment data, therefore, extend our knowledge of the functioning of the frontal ecosystem. For the typical Mediterranean and Atlantic waters, phytoplankton production is mostly involved in the microhial loop (regenerated production). On the other hand, the frontal system acts as a producer of matter whose greatest part is consumed by copepods and exported as fecal pellet. This is supported by floating sediment trap experiments; daily pigment exportation concerns $1 \% 0$ of the integrated biomass for sites 2 and 3 and $1 \%$ for the frontal site 5 (Prieur et al., 1993; Peinert and Miquel, 1994); moreover, pigments collected in sediment traps at the frontal sites are not completely degraded as phaeopigments (Claustre, unpublished results) which suggests that sedimentation is not only due to fecal pellets but also to diatom aggregates (Alldrege and Gotschalk, 1989). The frontal system acts not only as an enhanced production system but also as an export system that may supply the nutritional requirements of intermediate water zooplanktonic populations (Gorsky et al., 1991).

(2) The increase in the phaeopigment proportions from the left to the right side of the jet (leg B, Fig. 6) is supported by the overall distribution of the phaeopigment/chl $a$ ratio in the eastern Alboran basin (leg A, Fig. 13): high values of this ratio are associated with the jet and the isolines of this ratio are parallel to the current, the highest values being associated with its right side. Two explanations may be given. If the time required for fecal pellets to leave the first $150 \mathrm{~m}$ (depth of integration) is long (low sinking rate) in comparison with the time required for waters to go from the left to the right side of the jet, the increase in the phaeopigment $/ \mathrm{chl} a$ ratio is mainly due to accumulation of fecal pellets since grazing pressure (and grazer biomass) can be assumed to be constant over the jet section. On the other hand, if the sinking rate is high, there is no accumulation and the high value of the ratio at the right side should be the consequence of enhanced grazing pressure and zooplankton patches. Assuming a fecal pellet sinking rate of $100 \mathrm{~m} \mathrm{~d}^{-1}$ (Fowler and Knauer, 


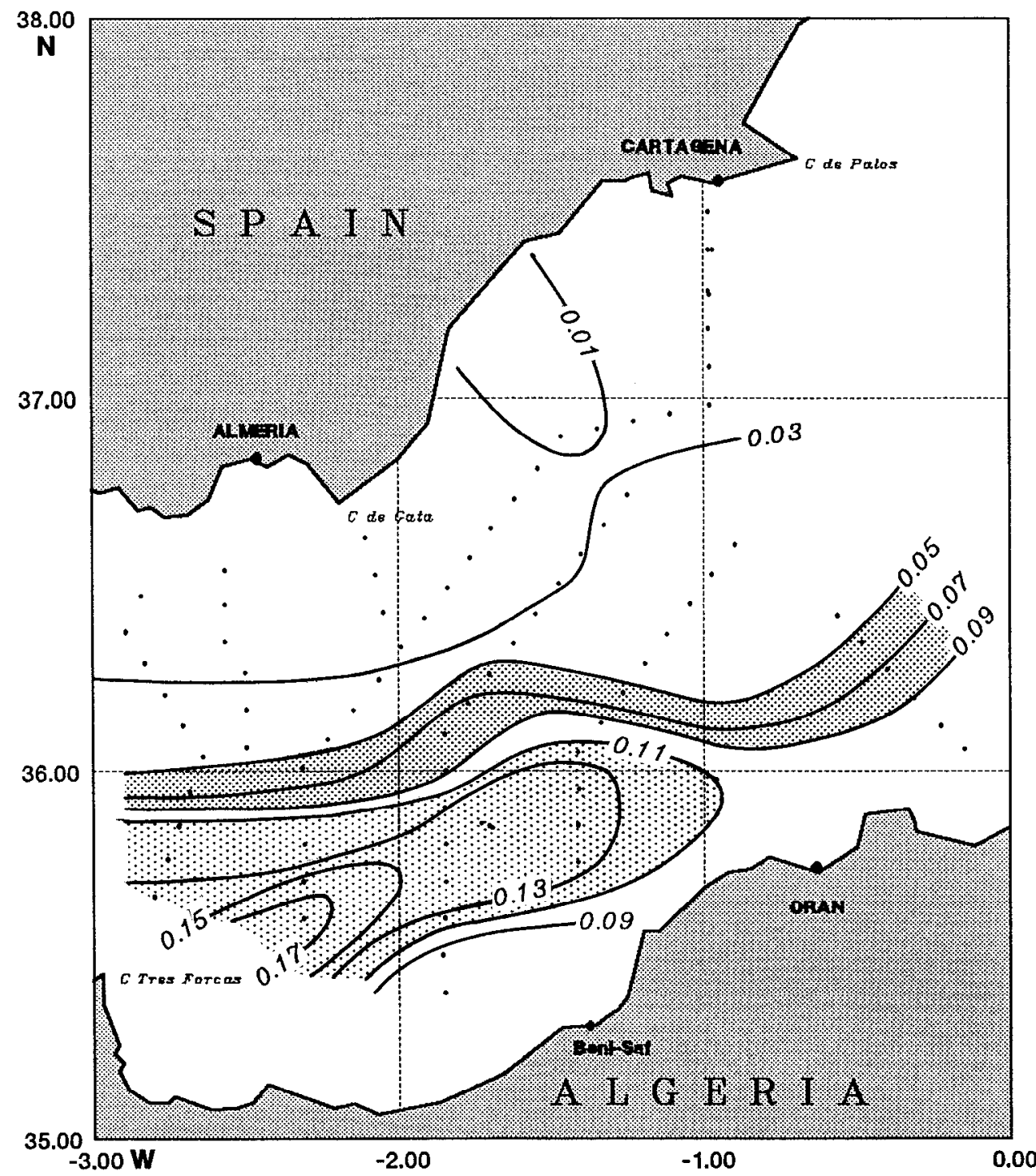

Figure 13. Contours of the ratio phaeopigments/chlorophyll $a$ (integrated values) in the Almeria-Oran front region.

1986), the time required to leave the top $150 \mathrm{~m}$ is 1.5 days which is certainly shorter than the transit time required from the left to the right side of the jet. Therefore, high values of the phaeopigment/chl $a$ ratio near the right side of the jet may result from enhanced grazing pressure, which confirm the observations of Thibault et al. (1994) who demonstrate that zooplankton activity and biomass were the highest at site 1 . In another geostrophic front in the Mediterranean Sea, Boucher et al. (1987) discov- 
ered the existence, near the convergence, of a preferential biotope for zooplankton populations which supports our conclusions.

\section{Concluding remarks}

"The Ocean's Deserts are blooming" is the title of Kerr's paper (1986) which is an accurate summary of the present investigation. In open-ocean waters, we observed eutrophic conditions that resulted from the abutment of two oligotrophic water masses. This observation has been examined from different angles.

The high biomass observed at the front was not duc to purely physical accumulation but rather to specific frontal processes which enhanced biological production. Cross frontal circulation is the likely candidate to sustain phytoplankton biomass development. From an ecological and geochemical point of view, the nature of the phytoplankton involved in the production is more important than the increase in production itself: diatoms comprise the greatest part of the primary production at this frontal system. This taxonomic group is an opportunistic group, typical of upwellings, that takes advantage of nitrate enrichment: it makes new production. As a consequence of the diatom bloom, the nature of the frontal food web is modified. The most likely grazers of diatoms are copepods which sustain the nutritional requirements of the higher trophic levels. Moreover, copepods produced fast sinking fecal material which, associated with ungrazed diatom aggregates significantly contribute to organic matter exportation. Therefore, since the jet-front system accounts for more than one half of phytoplankton biomass and for only one fifth of the surface area of the whole region, the influence of this mesoscale system on the cycling of matter may be essential at the basin scale.

Acknowledgments. This paper is a FRONTAL/INSU contribution. The authors wish to thank P. Morin for providing some nutrient data as well as $\mathbf{J}$. L. Birrien for supplying primary production data. Patrick Chang is acknowledged for english corrections.

\section{REFERENCES}

Alldrege, A. L. and C. C. Gotschalk. 1989. Direct observation of the mass floculation of diatom blooms: characteristics, settling velocities and formation of diatom aggregates. Deep-Sea Res., 36, 159-171.

Arnone, R. A., D. A. Wiesenburg, and K. D. Saunders. 1990. Acoustic imaging of biological and physical processes within Gulf Stream meanders. EOS Trans., Amer. Geophys. Union, $71,982$.

Arpin, N., W. A. Svec and S. Liaaen-Jensen. 1976. New-fucoxanthin-related carotenoids from Coccolithus huxleyi. Phytochem., 15, 529-532.

Barlow, R. G., P. H. Burkill and R. F. C. Mantoura. 1988. Grazing and degradation of algal pigments by the marine protozoan Oxyrhis marina. J. Exp. Mar. Biol. Ecol., 119, 119-129.

Barlow, R. G., R. F. C. Mantoura, M. A. Gough and T. W. Fileman. 1993. Pigments signatures of the phytoplankton composition in the North Eastern Atlantic during the 1990 spring bloom. Deep-Sea Res., 40, 459-477. 
Bjørnland, T., R. R. L. Guillard and S. Liaaen-Jensen. 1988. Phaeocystis sp. clone 667-3: a tropical marine Prymnesiophyte with fucoxanthin and 19' -acyloxyfucoxanthins as chemosystematic carotenoid markers. Biochem. System. Ecol., 16, 445-452.

Bjørnland, T., S. Liaaen-Jensen and J. Throndsen. 1989. Carotenoids of the marine chrysophyte Pelagoccocus subviridis. Phytochem., 28, 3347-3353.

Boucher, J., F. Ibanez and L. Prieur. 1987. Daily and seasonal variations in the spatial distribution of zooplankton populations in relation to the physical structure in the Ligurian front. J. Mar. Res., 45, 133-173.

Bower, A. S. and T. Rossby. 1989. Evidence of cross frontal exchange processes in the Gulf Stream based on isopycnal float data. J. Phys. Oceanogr., 19, 1177-1 190.

Carpenter, E. J. and L. Campbell. 1988. Diel patterns of cell division and growth rates of Synechoccocus spp. in Long Island Sound. Mar. Ecol. Progr. Ser., 47, 179-183.

Chavez, F. P., K. R. Buck, K. H. Coale, J. H. Martin, G. R. DiTullio, N. A. Welschmeyer, A. C. Jacobson and R. T. Barber. 1991. Growth rates, grazing, sinking, and iron limitation of equatorial Pacific phytoplankton. Limnol. Oceanogr., 36, 1816-1833.

Cheney, R. E. and R. A. Doblar. 1982. Structure and variability of the Alboran Sea Frontal System. J. Geophys. Res., 87, 585-594.

Claustre, H. and J. Gostan. 1987. Adaptation of biochemical composition and cell size to irradiance in two microalgae: possible ecological implications. Mar. Ecol. Progr. Ser., 40, $167-174$.

Claustre, H., J. C. Marty and L. Cassiani 1989. Intraspecific differences in the biochemical composition of a diatom during a spring bloom in Villefranche-sur-mer Bay, Mediterranean Sea. J. Exp. Mar. Biol. Ecol., 129, 17-32.

Claustre, H., S. A. Poulet, R. Williams, F. Ben Mlih, V. Martin-Jézéquel and J. C. Marty. 1992. Relation between the qualitative nature of particles and copepod feces in the Irish Sea. Mar. Chem., 40, 231-248.

Conover, R. J., R. Durvasula, S. Roy and R. Wang. 1986. Probable loss of chlorophyll-derived pigments during passage through the gut of zooplankton, and some of the consequences. Limnol. Oceanogr., 31, 878-887.

Coste, B., G. Jacques and H. J. Minas. 1977. Sels nutritifs et production primaire dans le golfe du Lion et ses abords. Ann. Inst. Océano., 53, 189-202.

Currie, R. I. 1962. Pigments in zooplankton fæces. Nature, 193, 956-957.

Dengler, A. T. 1985. Relationship between physical and biological processes at an upwelling front off Peru, 15S. Deep-Sea Res., 32, 1301-1315.

Dewey, R. K., J. N. Moum, C. A. Paulson, D. R. Caldwell and S. D. Pierce. 1991. Structure and dynamics of a coastal filament. J. Geophys. Res., 96, 14885-14907.

Durbin, E. G. 1977. Studies on the autoecology of the marine diatom Thalassiosira nordenskioeldii. II The influence of cell size on growth rate, and carbon, nitrogen, chlorophyll $a$ and silica content. J. Phycol., 13, 150-155.

Everitt, D. A., S. W. Wright, J. K. Volkman, D. P. Thomas and E. J. Lindstrom. 1990. Phytoplankton community compositions in the western equatorial Pacific determined from chlorophyll and carotenoid pigment distributions. Deep-Sea Res., 37, 975-997.

Fogg, G. E. 1991. The phytoplanktonic way of life. New Phytol., 118, 191-232.

Fowler, S. W. and G. A. Knauer. 1986. Role of large particles in the transport of elements and organic compounds through the oceanic water column. Prog. Oceanogr., 16, 147-194.

Franks, P. J. S. 1992a. Sink or swim: accumulation of biomass at fronts. Mar. Ecol. Prog. Ser., $82,1-12$. 
1992b. Phytoplankton blooms at fronts: patterns, scales and physical forcing mechanisms. Rev, Aqua. Sci., 6, 121-137.

Furnas, M. J. 1990. In situ growth rates of marine phytoplankton: approaches to measurement, community and species growth rates. J. Plankton Res., 12, 1117-1151.

- 1991. Net in situ growth rates of phytoplankton in an oligotrophic, tropical, shelf ecosystem. Limnol. Oceanogr., 36, 13-29.

Gieskes, W. W. C. and G. W. Kraay. 1983a. Unknown chlorophyll derivatives in the North Sea and the tropical Atlantic Ocean revealed by HPLC analysis. Limnol. Oceanogr., 28, $757-766$.

- 1983b. Dominance of cryptophyceae during the phytoplankton spring bloom in the central North Sea detected by HPLC analysis of pigments. Mar. Biol., 75, 179-185.

- 1986. Analysis of phytoplankton by HPLC, before during and after mass occurrence of the microflagellate Corymbellus aureus during the spring bloom in the open northern North Sea in 1983. Mar. Biol., 92, 45-52.

Gorsky, G., N. L. Da Silva, S. Dallot, Ph. Laval, J. C. Braconnot and L. Prieur. 1991. Midwater tunicates: are they related to the permanent front of the Ligurian Sea (NW Mediterranean)? Mar. Ecol. Prog. Ser., 74, 195-204.

Gotschalk, C. C. and A. L. Alldrege. 1989. Enhanced primary production and nutrient regeneration within aggregated marine diatoms. Mar. Biol., 103, 119-129.

Gould, R. W., Jr. and D. A. Wiesenburg. 1990. Single-species dominance in a subsurface phytoplankton concentration at a mediterranean Sea front. Limnol. Oceanogr., 35, 211220.

Guillard, R. R. L., L. S. Murphy, P. Foss and S. Liaaen-Jensen. 1985. Synenchoccocus spp. as likely zeaxanthin-dominant ultraplankton in the North Atlantic. Limnol. Oceanogr., 30, 412-414.

Harris, G. P. 1980. Temporal and spatial scales in phytoplankton ecology. Mechanisms, methods, models, and management. Can. J. Fish. Res. Aquat. Sci., 37, 877-900.

Heburn, G. and P. E. La Violette. 1987. Related variations in the structure of the anticyclonic gyres found in the Alboran sea. Eos Trans. Amer. Geophys. Union, 65, 682-683.

1990. Variations in the structure of the anticyclonic gyres found in the Alboran sea. J. Geophys. Res., 95, 1599-1613.

Herbland, A. 1988. The deep phaeopigments maximum in the ocean: reality or illusion? in Toward a Theory on the Biological-Physical Interactions in the World Ocean, B. J. Rotschild, ed., Kluwer Academic Publishers, 157-172.

Hooks, C. E., R. R. Bidigare, M. D. Keller and R. R. L. Guillard. 1988. Coccoid eukaryotic marine ultraplankters with four different HPLC pigment signatures. J. Phycol., 24, 571-580.

Jeffrey, S. W. 1974. Profiles of photosynthetic pigments in the central North Pacific Ocean. Mar. Biol., 37, 33-37.

1976. A report of green algae pigments in the central North Pacific Ocean. Mar. Biol., 37, 33-37.

1980. Algal pigment system, in Primary Productivity in the Sea, P. Falkowski, ed., Plenum Press, New York, 33-58.

Kana, T. M. and P. M. Glibert. 1987. Effect of irradiances up to $2000 \mu \mathrm{E} \cdot \mathrm{m}-2 \cdot \mathrm{s}-1$ on marine Synechoccocus WH7803-I. Growth, pigmentation and cell composition. Deep-Sea Res., 34, 479-495.

Kana, T. M., P. M. Glibert, R. Goericke and N. A. Welschmeyer. 1988. Zeaxanthin and $\beta$-carotene in Synechococcus WH7803 respond differently to irradiance. Limnol. Oceanogr., $33,1623-1627$. 
Kerr, R. A. 1986. The Ocean's Deserts are Blooming. Science, 232, 1345.

Klein, B., W. W. C. Gieskes and G. G. Kraay. 1986. Digestion of chlorophylls and carotenoids by the marine protozoan Oxyrrhis marina studied by HPLC analysis of algal pigments. J. Plank. Res., 8, 827-836.

Komar, P. D., A. P. Morse, I. F. Small and S. W. Fowler. 1981. Analysis of sinking rates of natural copepod and euphosiid fecal pellets. Limnol. Oceanogr., 26, 172-180.

Kranck, K. and T. G. Milligan. 1988. Macroflocs from diatoms: in situ photography of particles in Bedford Basin, Nova Scotia. Mar. Ecol. Progr. Ser., 44, 183-189.

Le Fèvre, J. 1986. Aspects of the biology of frontal systems. Adv. Mar. Biol., 23, 163-299.

Liaaen-Jensen, S. 1985. Carotenoids of lower plants-recent progress. Pure Appl. Chem., 57, 649-658.

Lohrenz, S. E., D. A. Wiesenburg, I. P. De Palma, K. S. Johnson and D. E. Gustafson. 1988a. Interrelationships among primary production, chlorophyll and environmental conditions in frontal regions of the western Mediterranean Sea. Deep-Sea Res., 35, 793-810.

Lohrenz, S. E., R. A. Arnone, D. A. Wiesenburg and I. P. De Palma. 1988b. Satellite detection of transient enhanced primary production in the western Mediterranean Sea. Nature, 335, 245-247.

Mantoura, R. F. C. and C. A. Llewellyn. 1983. The rapid determination of algal chlorophyll and carotenoid and their breakdown products in natural waters by reverse-phase highperformance liquid chromatography. Anal. Chem. Acta, 151, 297-314.

Morel, A., Y-W Ahn, F. Partensky, D. Vaulot, and H. Claustre. 1993. Prochlorococcus and Synechococcus: a compartive study of their size, pigmentation and related optical properties. J. Mar. Res., 51, 617-649.

Morel, A. and J.-F. Berthon. 1989. Surface pigments, algal biomass profiles, and potential production of the euphotic layer: relationships reinvestigated in view of remote-sensing applications. Limnol. Oceanogr., 34, 1541-1564.

Ondrusek, M. E., R. R. Bidigare, S. T. Sweet, D. A. Defreitas and J. M. Brooks. 1991. Distribution of phytoplankton pigments in the North Pacific Ocean in relation to physical and optical variability. Deep-Sea Res., 38, 243-266.

Peinert, R. and J. C. Miquel. 1994. The significance of frontal biological processes for vertical fluxes: a case study in the Alboran Sea. J. Mar. Sys., 5, (in press).

Pingree, R. and G. T. Mardell. 1981. Slope turbulence, internal waves and phytoplankton growth rate at the Celtic Sea shelf break. Phil. Trans. R. Soc. Lond., A302, 663-682.

Pingree, R., P. Pugh, P. M. Holligan and G. Forster. 1975. Summer phytoplankton blooms and red tides in the approaches to the English Channel. Nature. 258, 672-677.

Prieur, L., C. Copin-Montégut and H. Claustre. 1993. Biophysical aspects of ALMOFRONT 91, an intensive study of a gestrophic frontal jet. Ann Inst. Océano., 69, 71-86.

Shuman, F. R. and C. J. Lorenzen. 1975. Quantitative degradation of chlorophyll by a marine herbivore. Limnol. Oceanogr., 20, 581-586.

Simpson, J. H., D. J. Edlestein, A. Edwards, K. J. Jones, N. C. G. Morris and P. B. Tett. 1979. The Islay Front: Physical structure and phytoplankton distribution. Estuar. Coast. Shelf. Sci., 9, 713-726.

Simpson, J. II., P. B. Tett, M. L. Argottc-Espinoza, A. Edwards, K. J. Joncs and G. Savidge. 1982. Mixing and phytoplankton growth around an island in stratified sea. Cont. Shelf Res., $1,15-31$.

Soo IIo, J. B. and D. A. Kicfer. 1982. Vertical distribution of phacopigments. I. A simple grazing and photooxidative scheme for small particles. Deep-Sea Res., 29, 1539-1552. 
Sournia, A., J.-M. Brylinski, S. Dallot, P. Le Corre, M. Leveau, L. Prieur and C. Froget. 1990. Fronts hydrologiques au large des côtes françaises: les sites-ateliers du programme Frontal. Oceanologica Acta, 13, 413-437.

Thibault, D., R. Gaudy, and J. Le Fèvre. 1994. Zooplankton biomass, feeding and metabolism in a geostrophic area (Almeria-Oran front, eastern mediterranean). J. Mar. Sys., 5, (in press)

Tintoré, J., P. E. La Violette, I. Blade and A. Cruzado. 1988. A study of an intense density front in the eastern Alboran sea: The Almeria-Oran front. J. Phys. Oceanogr., 18, 13841397.

Townsend, D. W., C. M. Yentsch, C. E. Parker, W. M. Balch and E. D. True. 1983. An island mixing effect in the coastal Gulf of Maine. Helgoländer Meeresunters, 36, 347-356.

Traganza, E. D., D. G. Redalje and R. W. Garwood. 1987. Chemical flux, mixed layer entrainment and phytoplankton blooms at upwelling fronts in the California coastal zone. Cont. Shelf Res., 7, 89-105.

Vernet, M. and C. J. Lorenzen. 1987. The relative abundance of phaeophorbide $a$ and phaeophytin $a$ in temperate marine waters. Limnol. Oceanogr., 32, 352-358.

Videau, C. 1987. Primary production and physiological state of phytoplankton of the Ushant tidal front (West coast of Britany, France). Mar. Ecol. Prog. Ser., 35, 141-151.

Videau, C., A. Sournia, L. Prieur and M. Fiala. 1994. Phytoplankton and priary production characteristics at selected sites in the geostrophic Almeria-Oran front system (SW Mediterranean Sea). J. Mar. Sys., 5, (in press).

Weller, R. A. 1990. Not so quiet on the ocean front. Nature, 348, 199-200.

Welschmeyer, N. A. and C. J. Lorenzen. 1985. Chlorophyll budgets: zooplankton grazing and phytoplankton growth in a temperate fjord and the Central Pacific Gyres. Limnol. Oceanogr., 30, 1-21.

Williams, R. and H. Claustre. 1991. Chlorophylls and carotenoids as biomarkers of populations and processes involved in the transformation of the particulate organic matter at the biotrans site (45N, 18W). Deep-Sea Res., 38, 347-355.

Wright, S. W. and S. W. Jeffrey. 1987. Fucoxanthin pigment markers of marine phytoplankton analysed by HPLC and HPTLC. Mar. Ecol. Prog. Ser., 38, 259-266.

Received: 27July, 1993; revised: 3 January, 1994. 